\title{
Prograde and retrograde history of eclogites from the Eastern Blue Ridge, North Carolina, USA
}

\author{
F. Z. PAGE, E. J. ESSENE AND S. B. MUKASA \\ Department of Geological Sciences, University of Michigan, 2534 C.C. Little Building, Ann Arbor, MI 48109-1063, USA \\ (fpage@umich.edu)
}

ABSTRACT The prograde metamorphism of eclogites is typically obscured by chemical equilibration at peak conditions and by partial requilibration during retrograde metamorphism. Eclogites from the Eastern Blue Ridge of North Carolina retain evidence of their prograde path in the form of inclusions preserved in garnet. These eclogites, from the vicinity of Bakersville, North Carolina, USA are primarily comprised of garnet-clinopyroxene-rutile-hornblende-plagioclase-quartz. Quartz, clinopyroxene, hornblende, rutile, epidote, titanite and biotite are found as inclusions in garnet cores. Included hornblende and clinopyroxene are chemically distinct from their matrix counterparts. Thermobarometry of inclusion sets from different garnets record different conditions. Inclusions of clinozoisite, titanite, rutile and quartz (clinozoisite + titanite $=$ grossular + rutile + quartz $+\mathrm{H}_{2} \mathrm{O}$ ) yield pressures (6-10 kbar, 400-600 ${ }^{\circ} \mathrm{C}$ and 8-12 kbar 450-680 ${ }^{\circ} \mathrm{C}$ ) at or below the minimum peak conditions from matrix phases $\left(10-13 \mathrm{kbar}\right.$ at $\left.600-800{ }^{\circ} \mathrm{C}\right)$. Inclusions of hornblende, biotite and quartz give higher pressures $\left(13-16 \mathrm{kbar}\right.$ and $\left.630-660^{\circ} \mathrm{C}\right)$. Early matrix pyroxene is partially or fully broken down to a diopside-plagioclase symplectite, and both garnet and pyroxene are rimmed with plagioclase and hornblende. Hypersthene is found as a minor phase in some diopside + plagioclase symplectites, which suggests retrogression through the granulite facies. Two-pyroxene thermometry of this assemblage gives a temperature of $c$. $750{ }^{\circ} \mathrm{C}$. Pairing the most $\mathrm{Mg}$-rich garnet composition with the assemblage plagioclase-diopside-hypersthene-quartz gives pressures of $14-16 \mathrm{kbar}$ at this temperature. The hornblende-plagioclase-garnet rim-quartz assemblage yields $9-12 \mathrm{kbar}$ and $500-550{ }^{\circ} \mathrm{C}$. The combined $P-T$ data show a clockwise loop from the amphibolite to eclogite to granulite facies, all of which are overprinted by a texturally late amphibolite facies assemblage. This loop provides an unusually complete $P-T$ history of an eclogite, recording events during and following subduction and continental collision in the early Palaeozoic.

Key words: Blue Ridge; eclogite; prograde metamorphism; retrograde metamorphism; Southern Appalachians.

\section{INTRODUCTION}

Although the high variance assemblages that are typical of the eclogite facies present a significant barrier to precise thermobarometry (Essene, 1989), some eclogites preserve more diverse mineral assemblages both as relicts of their prograde development and as retrograde overprints. These assemblages are found as inclusions in and as partially re-equilibrated overgrowths on matrix phases, and can allow metamorphic petrologists to constrain the early and late stages of the $P-T$ paths of eclogites.

Other than studies that are focused on eclogite facies coronas on igneous assemblages (e.g. Chinner \& Dixon, 1973; Cox \& Indares, 1999 and references therein), research on the prograde histories of more fully recrystallized eclogites have focused on the preserved inclusions in garnet. Many of these studies do not include quantitative thermobarometry, but instead merely cite the presence of mineral inclusion assemblages typical of the amphibolite or greenschist facies.
Pognante et al. (1980) reported sodic-calcic amphibole, white mica and titanite inclusions in garnet from eclogites in the Sesia-Lanzo zone of the Italian Alps, interpreting them as part of a prograde greenschist assemblage. Venturini (1995) described actinolite, glaucophane, zoisite, quartz, chlorite and white mica defining a 'prograde foliation' within garnet in eclogites from the same region, concluding that the eclogites passed through the greenschist facies based on the presence of actinolite and chlorite. Franceschelli et al. (1998) identified tschermakitic amphibole and zoisite inclusions in garnet as possibly representing a prograde stage in the formation of eclogites in Sardinia. Möller (1998, 1999) described a retrogressed eclogite in southwestern Sweden with inclusions in garnet of quartz, titanite, rutile, plagioclase, clinopyroxene, hornblende, zoisite and kyanite, which may have been entrapped on the prograde path. Chemical analyses and thermometry have yet to be conducted on these assemblages. Oh \& Liou (1990) and Krogh et al. (1994) inferred three stages of prograde metamorphism recorded as 
inclusions of omphacite, epidote, ilmenite, titanite and three different compositions of amphibole in zoned garnet in eclogites from the Franciscan Complex, California, USA. These workers proposed an anticlockwise $P-T$ path based on estimates from a generalized petrogenetic grid of the metamorphic facies. Enami \& Nagasaki (1999) interpreted Fe-rich staurolite, paragonite and margarite inclusions in garnet cores in eclogites from the Su-Lu ultra high-pressure complex in Shandong Province, China to represent a prograde amphibolite facies assemblage. Although reduced activities were not fully taken into account in the thermobarometry, the assemblage is clearly outside the stability field of coesite, which is found in some Su-Lu eclogites.

A small number of studies (see below) have applied quantitative thermobarometry to inclusion assemblages in eclogitic garnet. Unfortunately, several of these studies apply thermometers and barometers to inclusion suites that do not contain the full reaction assemblage. The pressures and temperatures that result are treated as if they are fixed values rather than limits. Furthermore, a number of these studies make questionable assertions of equilibrium based on complicated textures.

Krogh (1982) characterized many different inclusions from a suite of Norwegian eclogites in his pioneering study of inclusions in eclogitic garnet. As in many studies that have followed, the bulk of the inclusions in garnet, and particularly those near the rims, were interpreted as part of a high-pressure assemblage. However, inclusions in the garnet cores were interpreted to be relicts of the amphibolite facies. Prograde pressures and temperatures were determined for two samples. In sample IB-3, a partially retrogressed eclogite from Framarsvik, Sunnfjord, prograde conditions of $6 \mathrm{kbar}$ and $535^{\circ} \mathrm{C}$ were based on the application of garnet-clinopyroxene thermometry and albite-jadeite-quartz barometry to a zoned clinopyroxene inclusion in garnet. Krogh noted that in the absence of plagioclase the barometer provides a lower pressure limit, but the pressure is, nonetheless, treated as an exact value in his summary $P-T$ diagram. A maximum prograde pressure of $9.5 \mathrm{kbar}$ at $590{ }^{\circ} \mathrm{C}$ for two samples (VP-1 \& VP-3) of eclogite from Verpeneset in the Nordfjord area is also plotted as a point in the summary $P-T$ diagram. Krogh's argument for this pressure/temperature maximum is based on the absence of paragonite in the garnet cores, coupled with the upper temperature stability of phengite (cf. fig. 6 of Krogh, 1982). Inclusions of paragonite, clinozoisite and quartz are found in an intermediate zone in some garnet, and Krogh suggested that the absence of paragonite in the core zone shows that the earlier prograde evolution of these eclogites was outside the stability field of paragonite in the presence of clinozoisite and quartz. Margarite and plagioclase are given as the lower pressure phases that react to form paragonite + clinozoisite + quartz, but they were not found in the core zone. The absence of paragonite in the core zone of the garnet should not be used to argue that it equilibrated outside of the stability field of paragonite + clinozoisite + quartz, unless the lowerpressure assemblage (margarite-plagioclase) is found as inclusions in that zone.

Elvevold \& Gilotti (2000) applied garnet-amphibole-plagioclase-quartz barometry on inclusions in garnet cores to infer a prograde epidote-amphibolite facies stage. In the absence of quartz inclusions, the prograde pressures of 10-11.5 kbar are upper limits and not exact values. However, as upper limits they nonetheless indicate prograde $P-T$ conditions compared to the inferred peak pressures of $>16 \mathrm{kbar}$.

Dachs \& Proyer (2001) reported a rich inclusion assemblage in garnet from retrogressed eclogites from the Tauern Window, Austria. Inclusions in garnet cores exhibit complex textures and zoning in amphibole and clinozoisite. Prograde conditions are reported as $400-440{ }^{\circ} \mathrm{C}$ and 5-6 kbar based on garnet-chlorite and amphibole-plagioclase thermometry and amphibole - chlorite barometry. Complex polymineralic inclusions with zoned minerals make thermobarometry rather uncertain, and it is unclear which composition of amphibole is taken to be in equilibrium with plagioclase. Amphibole-chlorite barometry is dependent on poorly understood solution chemistry of chlorite, and is crudely calibrated with temperature not considered as a variable. Although more and more eclogites are reported to record some of their prograde history based on inclusions in garnet, quantitative thermobarometry has been carefully applied in few if any of the studies.

The retrograde path of eclogites is generally much more easily evaluated than the prograde history or peak conditions, because most eclogites have some evidence of retrogression (Carswell, 1990), generally through the amphibolite or blueschist facies. Fewer eclogites have evidence of retrogression through the granulite facies. Aluminous eclogites that have experienced granulite facies retrograde conditions often contain symplectites of sapphirine, plagioclase, corundum and spinel after kyanite (e.g. O'Brien, 1997; Möller, 1999; Elvevold \& Gilotti, 2000; O'Brien \& Rötzler, 2003; and references therein). Eclogites with high-temperature overprints often also contain orthopyroxene replacing garnet and clinopyroxene (O'Brien, 1997).

In this study of Appalachian eclogites, textural and compositional evidence provides indications that inclusions were entrapped in garnet before the peak of metamorphism. Quantitative thermobarometry on included phases elucidates some of the prograde history of the eclogites, placing more precise constraints on prograde conditions than the limits applied in the past. Peak conditions are, as is often the case with eclogites, difficult to constrain beyond a pressure minimum. A retrograde overprint is texturally distinguishable from the peak assemblages in these partially 
decompressed eclogites. The mineralogically diverse assemblage of the retrograde overprint includes evidence of passage through the granulite facies.

\section{GEOLOGICAL SETTING}

Willard \& Adams (1994) first reported the existence of eclogites in the Eastern Blue Ridge, in the area around Bakersville, North Carolina. These eclogites are located near the base of the Ashe Metamorphic Suite (AMS), just above the Burnsville fault some $30 \mathrm{~km}$ west of the Grandfather Mountain Window (Fig. 1). The AMS is the lowest structural unit of the Spruce Pine thrust sheet, and is composed primarily of amphibolite facies metasedimentary rocks (Abbott \& Raymond, 1984). Eclogite blocks are found as pods in the AMS and range from a few metres square to c. $120 \mathrm{~m}$ thick and over a kilometre in length. Abbott \& Greenwood (2001) also presented evidence for decompressed eclogites about $50 \mathrm{~km}$ further north, near Boone, NC. The eclogite/high-pressure granulite of the Carolina Terrane in central South Carolina reported by Shervais et al. (2003) is unrelated to the Eastern Blue Ridge occurrences.

The Blue Ridge thrust complex in north-western North Carolina is a stack of four amphibolite to granulite facies metasedimentary thrust sheets, which dip to the south-east, and are bounded on the east by the Brevard Zone and the Inner Piedmont Terrane. The boundary between the lower three thrust sheets (Pardee Point, Beach Mountain, and Pumpkin Patch) and the uppermost sheet (Spruce Pine) is the Burnsville fault, an Acadian-age dextral strike-slip fault (Adams et al., 1995). The presence of Laurentian rocks to the west and eclogite and ultramafic rocks along the fault

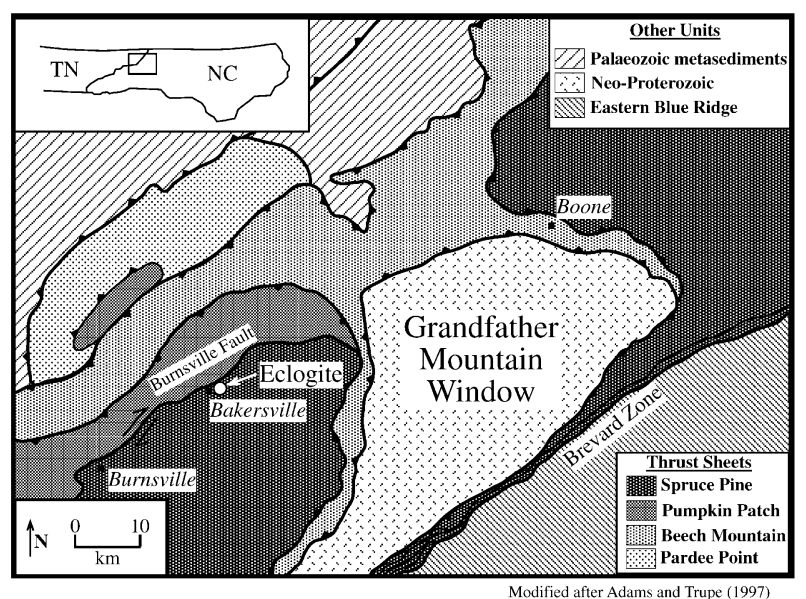

Fig. 1. Geological map of the Eastern Blue Ridge Thrust Complex, in western North Carolina (Adams \& Trupe, 1997). Eclogite is found at the bottom of the Spruce Pine thrust sheet, near the town of Bakersville, North Carolina (Willard \& Adams, 1994). The Burnsville fault has been interpreted as the Taconic suture in this region. $\mathrm{TN}=$ Tennessee, $\mathrm{NC}=$ North Carolina. zone have led many workers to believe that the Burnsville fault represents the Taconic suture in this area, which was later reactivated in the Acadian (Adams et al., 1995; Hatcher, 2001).

The interpretation that the Burnsville fault is part of the Taconic suture, a feature that is traceable along the length of the Appalachians, is widely accepted. However, there is some contention as to the provenance of the accreted terranes. The presence of blocks of eclogite, amphibolite and ultramafic rocks within the AMS, just above the suture, has been taken as evidence that the AMS represents an accretionary mélange (Abbott \& Raymond, 1984; Adams et al., 1995). Some workers have suggested that the eclogite and mélange formed as the Iapetus Ocean was subducted and the exotic Piedmont arc accreted onto the Laurentian margin (e.g. Adams et al., 1995; Miller \& Stewart, 2002).

Alternatively, the eastern Blue Ridge has been interpreted as a rifted fragment of Laurentia, re-attached during the Taconic orogeny (Hatcher, 1987). Middle Proterozoic detrital zircon has been found in metasediments of the Eastern Blue Ridge, as well as the Inner Piedmont. These zircon have been interpreted as having a Laurentian provenance based on their Grenvillian age. In this model, the Taconic suture was not the result of the closure of Iapetus, but the closure of a small oceanic basin (Hatcher, 2001; Bream et al., 2001). The similarity of Grenvillian basement across the western-eastern Blue Ridge contact has also caused some workers to suggest a Laurentian origin for the Piedmont Terrane (Carrigan et al., 2003).

\section{TEXTURAL RELATIONS AND PETROGRAPHY}

Samples of eclogite were collected from a road cut on the west side of Young Road some $500 \mathrm{~m}$ north of Bakersville and from along Lick Ridge some $3 \mathrm{~km}$ north-east of town. Sample locations are available in Page (2001). The eclogite is typically massive, although it shows compositional layering in places, with alternating garnet- and pyroxene-rich layers up to a few centimetres in thickness. In one case a $2-\mathrm{cm}$ thick garnet layer was found to be almost monomineralic. Garnet, clinopyroxene, amphibole, rutile, plagioclase, and quartz are evident in hand sample, with garnet ranging from sub-millimetre to one-centimetre size. In all cases, at least some hornblende is visible in hand sample, and the samples collected reflect a continuum between eclogite to retrogressed eclogite and garnet amphibolite. In many samples, especially those with larger garnet, thin $(<1 \mathrm{~mm})$ haloes of plagioclase and hornblende are present around the garnet. The eclogite bodies do not show progressive zonation of amphibole from core to rim of the pods. However, amphibolitization is greater around fractures and veins in the rock. In one case, a $c .1 \mathrm{~cm}$ wide epidote vein cuts through eclogite and shows a clear alteration front with massive amphibole within $3-4 \mathrm{~cm}$ of the vein, grading into amphibole-rich eclogite. Although all samples of eclogitic rocks from the Bakersville area are variably amphibolitized, most samples are composed of the eclogitic assemblage: clinopyroxene-garnet-quartzrutile.

The samples from the Bakersville and Lick Ridge localities show textures previously described by Willard \& Adams (1994), although a more diverse mineralogy has been observed in both the matrix and garnet inclusion assemblages in this study. Hypersthene, plagioclase, hornblende and epidote are found in the matrix, and garnet contains inclusions of quartz, rutile, clinopyroxene, 
hornblende, epidote, titanite and biotite. Back-scattered electron (BSE) images have been obtained with the University of Michigan Hitatchi scanning electron microscope (SEM) in order to illustrate mineralogy and textures.

Matrix clinopyroxene grains range in diameter from $c .100 \mu \mathrm{m}$ to c. $7 \mathrm{~mm}$. The least overprinted grains have large, pale green, plagioclase-free cores surrounded by thin rims of clinopyroxene-plagioclase symplectite (Fig. 2a). Small needles of quartz are found within the cores of some crystals. The more overprinted samples have small or no plagioclase-free cores, and have abundant hornblende intergrown with the symplectite rims. In some cases, relict clinopyroxene grains are almost completely replaced with hornblende. In two samples (99BK-02 \& 01LR-04) small $(c .30 \mu \mathrm{m})$ grains of hypersthene were found within the clinopyroxene-plagioclase symplectite (Fig. 2b).

Garnet is generally subhedral, and is rimmed in almost all cases by hornblende, plagioclase and quartz. In more heavily retrogressed samples these rims are wider (up to $c .70 \mu \mathrm{m}$ ), and garnet is slightly embayed. The garnet ranges in size from $c .100 \mu \mathrm{m}$ to $c .10 \mathrm{~mm}$. Almost all of these garnet contain abundant inclusions in their cores and have inclusion-poor or inclusion-free rims (Fig. 2c). The largest garnet contain many inclusions, which are more widely disseminated throughout the crystals (Fig. 2d), and which do not have discernable inclusion-free rims.

Quartz ranging in size from 1 to $150 \mu \mathrm{m}$ is the most common inclusion in garnet (Fig. 2c,d). Although inclusions have been observed along cracks, no radial cracks were seen in the garnet around quartz inclusions, nor were polycrystalline or palisade quartz grains found, suggesting that these inclusions were not inverted from coesite (Chopin, 1984).

Rutile is almost ubiquitous as inclusions in garnet. Although some range in size up to $50 \mu \mathrm{m}$, most are $c$. $1 \mu \mathrm{m}$ tablets or rods widely disseminated in the garnet cores. Some larger rutile have thin $(c .1 \mu \mathrm{m}$ width) blades of ilmenite in them. Epidote inclusions, which are quite variable in size $(5-300 \mu \mathrm{m})$, are also common in garnet cores, and have no zoning (Fig. 2e).

Clinopyroxene inclusions in garnet are less common than epidote, and range in size from 5 to $50 \mu \mathrm{m}$. Compound inclusions with quartz are rare, and plagioclase inclusions have not been found. Hornblende ranging in size from 10 to $200 \mu \mathrm{m}$ is also found as inclusions in garnet (Fig. 2e,f). Biotite inclusions were found in garnet from five samples. In two samples $100 \mu \mathrm{m}$-size biotite grains form compound inclusions with hornblende (Fig. 2f). Garnet from the Bakersville area also contains inclusions of apatite, zircon, $\mathrm{Fe}, \mathrm{Cu}$ and $\mathrm{Ni}$ sulphides.

In addition to the predominant matrix phases garnet and clinopyroxene, retrograde hornblende and plagioclase, polygonal crystals of quartz are present in the matrix along with rutile (which is variably altered to ilmenite or titanite) and epidote. Matrix epidote has patchy zoning in LREE and Th.

\section{MINERAL CHEMISTRY}

Minerals of interest have been analyzed using the Cameca CAMEBAX electron microprobe (EMP) at the University of Michigan. Most minerals were analyzed in point beam mode at $15 \mathrm{kV}$ and $10 \mathrm{nA}$, except for feldspar and biotite, which were analyzed using a $3 \mu \mathrm{m}^{2}$ rastered beam to limit volatilization. Natural and synthetic standards were used, and data was reduced using a Cameca PAP-type correction (Pouchou \& Pichoir, 1984).

Pyroxene formulae were calculated and $\mathrm{Fe}^{2+} / \mathrm{Fe}^{3+}$ ratios were estimated by normalizing the analyses to 4 cations and 6 oxygen (Table 1). Similar to the study by Willard \& Adams (1994), matrix clinopyroxene has omphacitic cores $\left(\mathrm{Jd}_{20}-\mathrm{Jd}_{30}\right)$ and rims of diopside $\left(\mathrm{Di}_{66} \mathrm{Hd}_{22} \mathrm{CaTs}_{2}\right)$ intergrown with plagioclase $\left(\mathrm{Ab}_{75} \mathrm{An}_{25}\right)$. Clinopyroxene cores from more overprinted samples have lower jadeite $\left(\sim \mathrm{Jd}_{10}\right)$ and have higher Ca-Tschermak's contents $\left(\mathrm{CaTs}_{15-20}\right)$ than more pristine samples. When plotted on a Jd-CaTs-Di + Hd ternary diagram, pyroxene compositions form an array of changing clinopyroxene composition during prograde and retrograde conditions (Fig. 3). Hypersthene $\left(\mathrm{En}_{68} \mathrm{Fs}_{32}\right)$ is rarely intergrown with the diopside-plagioclase symplectite (Fig. 2b).

Clinopyroxene inclusions are unzoned and range in composition from $\mathrm{Jd}_{3} \mathrm{CaTs}_{8} \mathrm{Di}_{65} \mathrm{Hd}_{24}$ to $\mathrm{Jd}_{20} \mathrm{CaTs}_{5^{-}}$ $\mathrm{Di}_{55} \mathrm{Hd}_{20}$. They are generally lower in Ca-Tschermak's than matrix clinopyroxene of similar jadeite content, and they form an array on the $\mathrm{Jd}-\mathrm{CaTs}-\mathrm{Di}+\mathrm{Hd}$ diagram that overlaps only slightly with that of matrix clinopyroxene compositions (Fig. 3). Clinopyroxene inclusions have lower jadeite content than matrix clinopyroxene cores, which may suggest that they were preserved from the time of prograde garnet growth before reaching the eclogite facies baric maximum.

Garnet formulae were normalized to 12 oxygen atoms with all $\mathrm{Fe}$ assumed to be $\mathrm{Fe}^{2+}$ (Table 2). Garnet cores show little zoning with a typical composition of $\mathrm{Alm}_{43} \mathrm{Pyp}_{32} \mathrm{Grs}_{24} \mathrm{Sps}_{1}$. Most garnet has 50 $100 \mu \mathrm{m}$ rims with lower $\mathrm{Mg}$ and higher $\mathrm{Fe}$ content typical of retrograde zoning (Fig. 4). The change in $\mathrm{Fe} / \mathrm{Mg}$ is coupled with a minor decrease in $\mathrm{Ca}$ content $\left(\mathrm{Alm}_{49} \mathrm{Pyp}_{27} \mathrm{Grs}_{22} \mathrm{Sps}_{2}\right)$. Smaller garnet $(<300 \mu \mathrm{m})$ are not zoned, and has compositions similar to that of the larger garnet rims. The zoning present in garnet rims does not coincide with the change in inclusion abundance typical in most Bakersville eclogite garnet; no chemical gradient is present at the boundary between inclusion-rich cores and inclusion-poor rims (Fig. 4).

Epidote formulae were normalized to 12.5 oxygen atoms with $\mathrm{Fe}$ and $\mathrm{Mn}$ assumed to have a $3^{+}$valence (Table 3). Epidote inclusions in garnet are unzoned and have the composition $\mathrm{Cz}_{85} \mathrm{Ps}_{15}$. Matrix epidote $\left(\mathrm{Cz}_{82} \mathrm{Ps}_{12} \mathrm{All}_{6}\right)(\mathrm{All}=$ allanite$)$ was found to have patchy zoning in REE.

Hornblende formulae were normalized to 13 small cations $\left(\mathrm{Si}, \mathrm{Ti}, \mathrm{Al}, \mathrm{Cr}, \mathrm{Fe}, \mathrm{Mn}\right.$ and $\mathrm{Mg}$ ) with $\mathrm{Fe}^{2+}$ / $\mathrm{Fe}^{3+}$ adjusted to yield 46 negative charges (Table 4). They were classified following the scheme of Leake et al. (1997). Unzoned grains in the pargasite and edenite fields occur both in the matrix and as inclusions (Fig. 5). Hornblende will be used in this paper as a group name for these calcic amphiboles. Although matrix and inclusion hornblende compositions largely overlap, included hornblende has $0.9-1.3$ wt. \% $\mathrm{K}_{2} \mathrm{O}$, whereas matrix hornblende contains significantly less $\mathrm{K}_{2} \mathrm{O} \quad(<0.1-0.5$ wt. \%). The two populations of hornblende are thus distinct both texturally and compositionally. Although the matrix hornblende is likely a product of retrograde reactions, it seems likely that the included hornblende as well as pyroxene were entrapped in the garnet during prograde growth. 

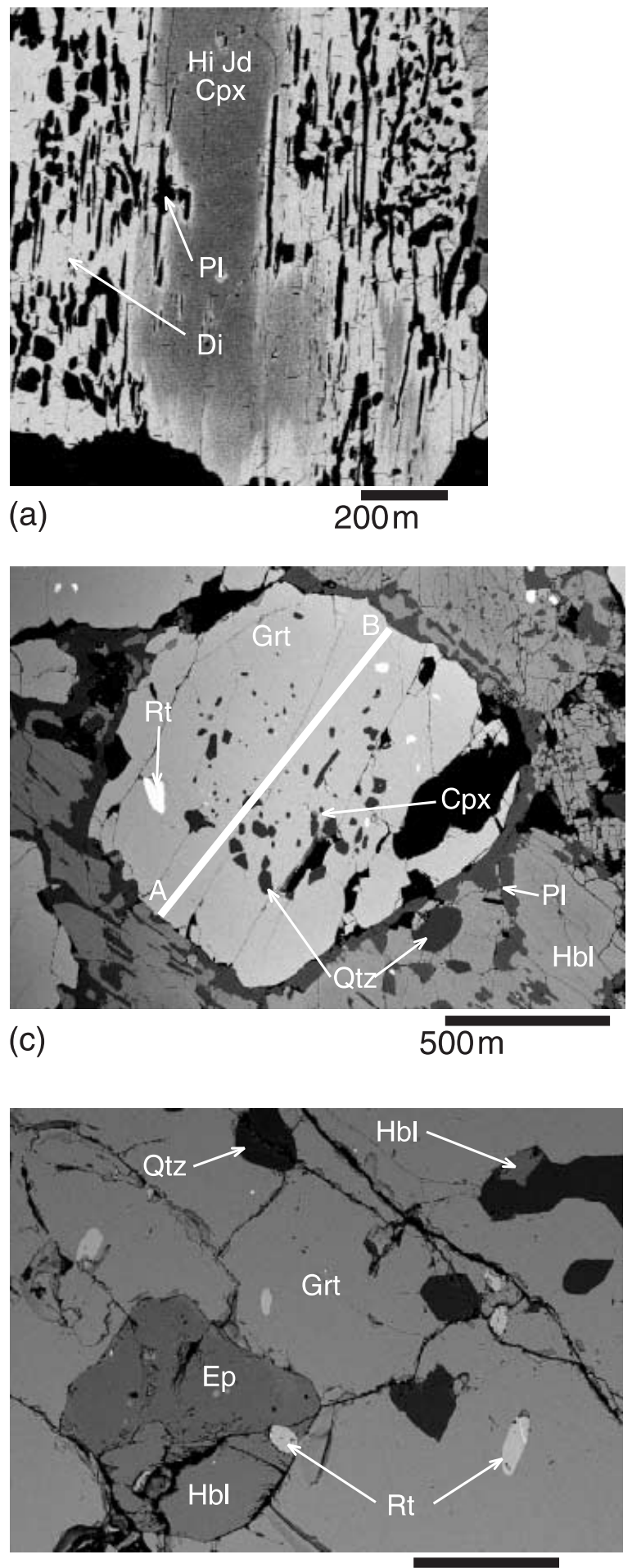

(e)

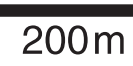

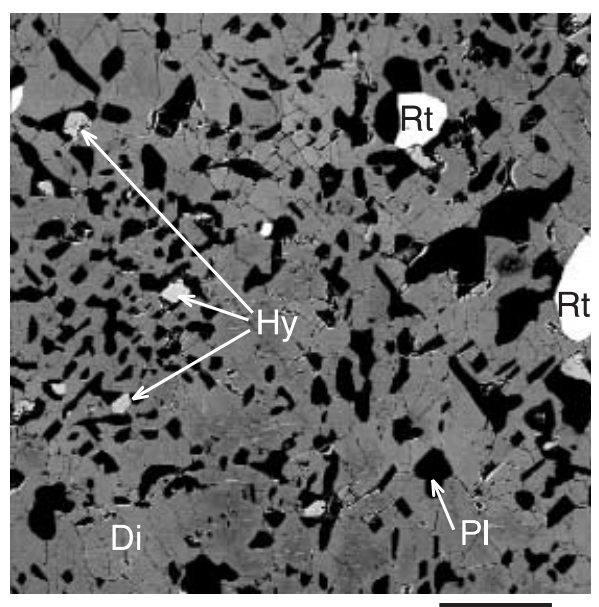

(b)

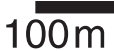

(d)

$250 \mathrm{~m}$

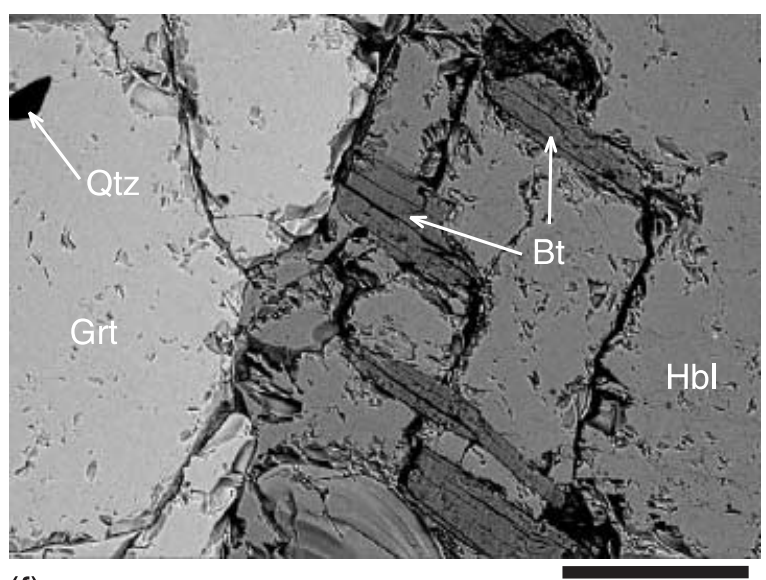

(f)

Fig. 2. Back-scattered electron (BSE) images. (a) Matrix clinopyroxene from sample 99BK-01. The more jadeitic clinopyroxene (Hi Jd $\mathrm{Cpx}$ ) core is surrounded by a plagioclase ( $\mathrm{Pl}$ ) - diopside (Di) symplectite. (b) Hypersthene (Hy, areas of medium brightness) in a diopside - plagioclase symplectite with rutile inclusions (Rt) in sample 99BK-02. (c) Garnet (Grt) from sample 99BK-02. The garnet has an inclusion-rich core with quartz (Qtz), rutile and one clinopyroxene grain. The garnet is rimmed with plagioclase and is surrounded by hornblende $(\mathrm{Hbl})$. An electron microprobe traverse was conducted along the line A-B. (d) Large garnet with inclusions from sample 99BK-01. The garnet contains inclusions of quartz, rutile, epidote (Ep), titanite (Ttn), apatite (Ap) and zircon (Zrn), and is rimmed with hornblende and plagioclase. (e) BSE of inclusions of hornblende, epidote, quartz, and rutile in a garnet from sample 01LR-01b. (f) BSE image of a compound biotite (Bt)-hornblende inclusion in a garnet from sample 01LR-01b. 
Table 1. Representative electron microprobe analyses of pyroxene. $^{\text {a }}$

\begin{tabular}{|c|c|c|c|c|c|c|c|}
\hline & 1 & 2 & 3 & 4 & 5 & 6 & 7 \\
\hline $\mathrm{SiO}_{2}$ & 53.49 & 51.22 & 53.66 & 51.19 & 52.17 & 50.43 & 52.64 \\
\hline $\mathrm{TiO}_{2}$ & 0.19 & 0.19 & 0.35 & 0.48 & 0.02 & 0.33 & 0.30 \\
\hline $\mathrm{Al}_{2} \mathrm{O}_{3}$ & 8.46 & 3.64 & 8.99 & 5.73 & 0.98 & 5.89 & 5.28 \\
\hline $\mathrm{Cr}_{2} \mathrm{O}_{3}$ & 0.03 & 0.07 & 0.01 & n.d. & n.d. & n.d. & 0.02 \\
\hline $\mathrm{MgO}$ & 10.67 & 13.30 & 9.18 & 11.20 & 24.30 & 12.23 & 11.99 \\
\hline $\mathrm{FeO}$ & 6.35 & 8.39 & 6.86 & 8.29 & 21.33 & 8.55 & 8.27 \\
\hline $\mathrm{MnO}$ & n.d. & 0.06 & 0.01 & 0.05 & 0.19 & 0.05 & 0.06 \\
\hline $\mathrm{CaO}$ & 16.76 & 21.61 & 16.69 & 20.54 & 0.36 & 20.84 & 19.42 \\
\hline $\mathrm{Na}_{2} \mathrm{O}$ & 4.13 & 1.26 & 4.55 & 1.76 & n.d. & 1.47 & 2.68 \\
\hline Sum & 100.09 & 99.73 & 100.30 & 99.24 & 99.35 & 99.79 & 100.65 \\
\hline $\mathrm{Si}$ & 1.93 & 1.89 & 1.94 & 1.91 & 1.93 & 1.86 & 1.92 \\
\hline $\mathrm{Al}^{(\mathrm{IV})}$ & 0.07 & 0.11 & 0.06 & 0.09 & 0.04 & 0.14 & 0.08 \\
\hline $\mathrm{Al}^{(\mathrm{VI})}$ & 0.29 & 0.05 & 0.32 & 0.16 & n.d. & 0.12 & 0.14 \\
\hline $\mathrm{Ti}$ & $<0.01$ & $<0.01$ & 0.01 & 0.01 & $<0.01$ & $<0.01$ & $<0.01$ \\
\hline $\mathrm{Fe}^{3+}$ & 0.06 & 0.13 & 0.04 & 0.04 & 0.09 & 0.10 & 0.12 \\
\hline $\mathrm{Fe}^{2+}$ & 0.13 & 0.13 & 0.17 & 0.22 & 0.57 & 0.16 & 0.14 \\
\hline $\mathrm{Cr}$ & $<0.01$ & $<0.01$ & $<0.01$ & n.d. & n.d. & n.d. & $<0.01$ \\
\hline $\mathrm{Mn}$ & n.d. & $<0.01$ & $<0.01$ & $<0.01$ & $<0.01$ & $<0.01$ & $<0.01$ \\
\hline $\mathrm{Mg}$ & 0.57 & 0.73 & 0.49 & 0.62 & 1.34 & 0.67 & 0.65 \\
\hline $\mathrm{Ca}$ & 0.65 & 0.86 & 0.65 & 0.82 & 0.01 & 0.83 & 0.76 \\
\hline $\mathrm{Na}$ & 0.29 & 0.09 & 0.32 & 0.13 & n.d. & 0.11 & 0.19 \\
\hline
\end{tabular}

${ }^{a}$ Formulae normalized to 4 cations, $\mathrm{Fe}^{2+} / \mathrm{Fe}^{3+}$ estimated by normalizing to $6 \mathrm{O}$; n.d. not detected. Matrix clinopyroxene: 99BK-02 core [no. 1], 99BK-02 rim [no. 2], 01LR-05b core [no. 3], 01LR-05b [no. 4]. Orthopyroxene: 99BK-02 [no. 5]. Matrix clinopyroxene with orthopyroxene: 99BK-02 [no. 6]. Clinopyroxene inclusion in garnet: 01LR-04 [no. 7].

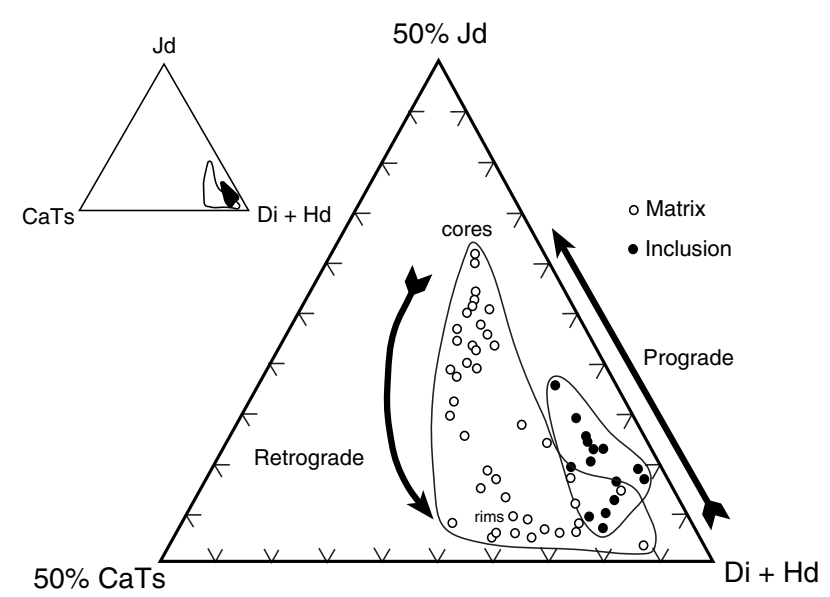

Fig. 3. Compositions of clinopyroxene shown in Jd-CaTs-Di + Hd space. Matrix clinopyroxene shown as open circles, inclusion clinopyroxene as filled circles. Matrix clinopyroxene compositions have little overlap with inclusion compositions suggesting that included clinopyroxene may have been entrapped on the prograde path. Matrix compositions define a path from jadeitic cores to diopsidic rims.

Formulae for feldspar were calculated on the basis of 8 oxygen atoms per formula unit (Table 5). All feldspar is unzoned oligoclase $\left(\mathrm{Ab}_{69-77} \mathrm{An}_{30-23} \mathrm{Or}_{01}\right)$ both in diopside/plagioclase symplectites on clinopyroxene rims and in hornblende/plagioclase symplectites surrounding garnet.
Table 2. Representative electron microprobe analyses of garnet. $^{\mathrm{a}}$

\begin{tabular}{lrrrr}
\hline & 1 & 2 & 3 & 4 \\
\hline $\mathrm{SiO}_{2}$ & 39.71 & 39.14 & 39.53 & 38.76 \\
$\mathrm{TiO}_{2}$ & 0.06 & 0.03 & 0.08 & 0.08 \\
$\mathrm{ZrO}_{2}$ & 0.01 & 0.03 & n.d. & n.d. \\
$\mathrm{Al}_{2} \mathrm{O}_{3}$ & 22.16 & 21.82 & 21.91 & 21.63 \\
$\mathrm{Cr}_{2} \mathrm{O}_{3}$ & 0.06 & 0.05 & 0.05 & 0.05 \\
$\mathrm{Y}_{2} \mathrm{O}_{3}$ & n.d. & n.d. & n.d. & n.d. \\
$\mathrm{FeO}$ & 20.14 & 22.24 & 22.20 & 24.47 \\
$\mathrm{MnO}$ & 0.44 & 0.57 & 0.45 & 0.84 \\
$\mathrm{MgO}$ & 8.73 & 7.63 & 8.16 & 5.92 \\
$\mathrm{CaO}$ & 9.23 & 8.04 & 7.75 & 8.06 \\
$\mathrm{Total}$ & 100.54 & 99.55 & 100.13 & 99.80 \\
$\mathrm{Si}$ & 3.00 & 3.01 & 3.01 & 3.01 \\
$\mathrm{Ti}$ & $<0.01$ & $<0.01$ & $<0.01$ & $<0.01$ \\
$\mathrm{Al}$ & 1.97 & 1.98 & 1.97 & $<.98$ \\
$\mathrm{Cr}$ & $<.01$ & $<0.01$ & $<0.01$ & $<0.01$ \\
$\mathrm{Fr}$ & 1.27 & 1.43 & 1.42 & 1.59 \\
$\mathrm{Mn}$ & 0.03 & 0.04 & 0.03 & 0.06 \\
$\mathrm{Mg}$ & 0.98 & 0.87 & 0.93 & 0.68 \\
$\mathrm{Ca}$ & 0.75 & 0.66 & 0.63 & 0.67 \\
$\mathrm{Alm}$ & 42 & 48 & 47 & 53 \\
$\mathrm{Pyp}$ & 32 & 29 & 31 & 23 \\
$\mathrm{Grs}$ & 25 & 22 & 21 & 22 \\
$\mathrm{Sps}$ & 1 & 1 & 1 & 2 \\
\hline
\end{tabular}

${ }^{a}$ Formulae normalized to 8 cations; n.d. not detected. Garnet core: 99BK-02 [no. 1], 01LR04 [no. 3]. Garnet rim: $99 \mathrm{BK}-01$ [no. 2], $01 \mathrm{LR}-04$ [no. 4].

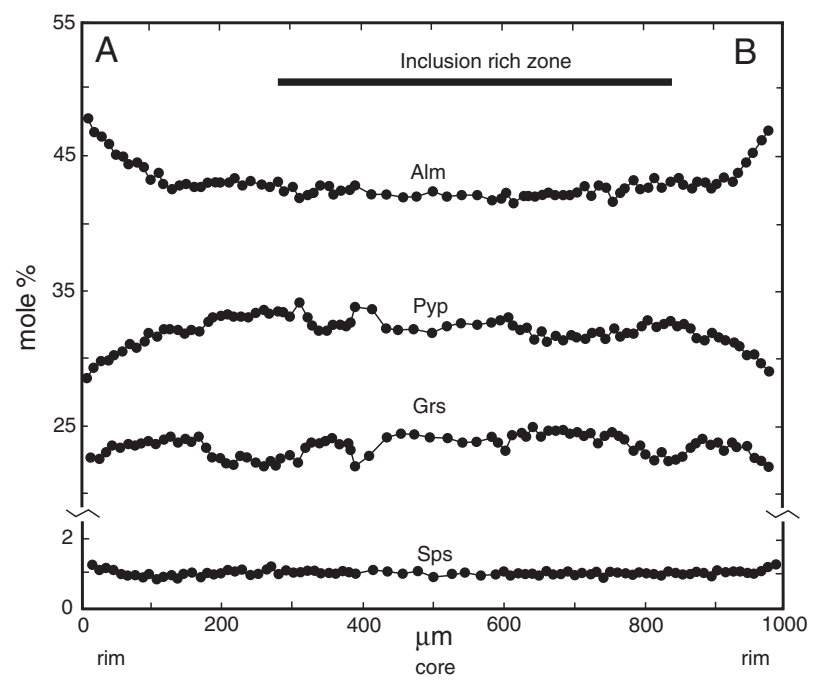

Fig. 4. Profile of the garnet in Fig. 2(c) along line A-B. Garnet compositions reported in mole percentage end-members.

Biotite formulae were normalized to 14 small cations (Table 4). All Fe was assumed to be ferrous. Biotite compositions are intermediate between phlogopite and annite $\left(\mathrm{Phl}_{60} \mathrm{Ann}_{40}\right)$. Biotite also contains an eastonite component $\left(\mathrm{Al}^{\mathrm{VI}}=c .1\right.$ atom per formula unit $)$. Although the ferric iron content of the biotite could not be estimated, the effect of 10 and $20 \%$ of the total iron as ferric was tested in thermobarometric calculations involving biotite. 
Table 3. Representative electron microprobe analyses of epidote $^{\mathrm{a}}$, titanite $^{\mathrm{b}}$ and rutile. ${ }^{\mathrm{c}}$

\begin{tabular}{|c|c|c|c|c|}
\hline & 1 & 2 & 3 & 4 \\
\hline $\mathrm{SiO}_{2}$ & 37.84 & 30.03 & 0.06 & 0.01 \\
\hline $\mathrm{TiO}_{2}$ & 0.26 & 36.90 & 96.97 & 99.03 \\
\hline $\mathrm{ZrO}_{2}$ & 0.02 & n.d & 0.06 & 0.02 \\
\hline $\mathrm{Nb}_{2} \mathrm{O}_{5}$ & 0.01 & n.d & 0.03 & 0.02 \\
\hline $\mathrm{Ta}_{2} \mathrm{O}_{5}$ & n.d & n.d & n.d & n.d \\
\hline $\mathrm{Al}_{2} \mathrm{O}_{3}$ & 27.84 & 1.48 & 0.04 & n.d \\
\hline $\mathrm{Fe}_{2} \mathrm{O}_{3}$ & 6.98 & 0.49 & 0.95 & 0.11 \\
\hline $\mathrm{Mn}_{2} \mathrm{O}_{3}$ & 0.02 & n.a. & n.a. & n.a. \\
\hline $\mathrm{Cr}_{2} \mathrm{O}_{3}$ & 0.17 & 0.09 & 0.03 & 0.01 \\
\hline $\mathrm{V}_{2} \mathrm{O}_{3}$ & n.a. & n.a. & 0.83 & 0.82 \\
\hline $\mathrm{Y}_{2} \mathrm{O}_{3}$ & n.d & n.d & n.a. & n.a. \\
\hline $\mathrm{La}_{2} \mathrm{O}_{3}$ & n.d & n.d & n.a. & n.a. \\
\hline $\mathrm{Ce}_{2} \mathrm{O}_{3}$ & n.d & n.d & n.a. & n.a. \\
\hline $\mathrm{Nd}_{2} \mathrm{O}_{3}$ & 0.06 & n.d & n.a. & n.a. \\
\hline $\mathrm{MnO}$ & n.a. & 0.03 & 0.03 & 0.00 \\
\hline $\mathrm{MgO}$ & 0.03 & n.d & 0.01 & 0.01 \\
\hline $\mathrm{CaO}$ & 24.13 & 28.76 & 0.34 & 0.10 \\
\hline $\mathrm{SrO}$ & 0.13 & n.d & n.a. & n.a. \\
\hline F & 0.00 & 0.10 & n.a. & n.a. \\
\hline $\mathrm{H}_{2} \mathrm{O}$ & 1.91 & 0.32 & n.c. & n.c. \\
\hline Sum & 99.40 & 98.18 & 99.37 & 100.14 \\
\hline $\mathrm{Si}$ & 2.97 & 1.00 & 0.00 & 0.00 \\
\hline $\mathrm{Al}^{\mathrm{IV}}$ & 0.03 & n.c. & n.c. & n.c. \\
\hline $\mathrm{Al}^{\mathrm{VI} .}$ & 2.54 & 0.06 & n.d. & n.d. \\
\hline $\mathrm{Fe}^{3+}$ & 0.41 & 0.01 & 0.01 & n.d. \\
\hline $\mathrm{Ti}$ & 0.02 & 0.92 & 0.98 & 0.99 \\
\hline $\mathrm{Ca}$ & 2.03 & 1.03 & n.d. & n.d. \\
\hline $\mathrm{Sr}$ & 0.01 & n.d. & n.a. & n.a. \\
\hline $\mathrm{F}$ & n.a. & 0.01 & n.a. & n.a. \\
\hline $\mathrm{OH}$ & 1.00 & 0.07 & 0.02 & 0.01 \\
\hline
\end{tabular}

${ }^{\mathrm{a}}$ Formula normalized to 12.5 oxygen. ${ }^{\mathrm{b}}$ Formula normalized to $1 \mathrm{Si}^{\mathrm{c}}{ }^{\mathrm{c}}$ Formulae normalized to 1 cation. n.a. not analyzed, n.d. not detected, n.c. not calculated. Inclusion epidote 99LR02 [no. 1]. Inclusion titanite 99LR-02 [no. 2]. Inclusion rutile 99LR-02 [no. 3]. Matrix rutile 99BK-01 [no. 4].

Rutile was analyzed for $\mathrm{Ti}, \mathrm{Fe}, \mathrm{Al}, \mathrm{Nb}, \mathrm{Cr}$ and $\mathrm{V}$. Overlap between $\mathrm{V}$ and $\mathrm{Ti}$ peaks was corrected by analyzing a $\mathrm{V}$ free rutile standard for $\mathrm{V}$, then subtracting this apparent $\mathrm{V}$ due to peak overlap from the analyses of unknowns. Rutile formulae were normalized to one cation per formula unit (Table 3). The substitution of $\mathrm{Al}$ is negligible, although minor $\mathrm{Fe}^{3+}$ substitution, $<0.6 \mathrm{~mol} \% \mathrm{FeO}(\mathrm{OH})$, was observed. Matrix and inclusion compositions are similar, with included rutile containing slightly more $\mathrm{FeO}(\mathrm{OH})$ substitution $(0.4-0.6 \mathrm{~mol} \%)$ than matrix rutile $(0.1-$ $0.5 \mathrm{~mol}$ percentage). Titanite inclusions in garnet were analyzed and normalized to one $\mathrm{Si}$ atom. Only minor substitution of $\mathrm{Al}, \mathrm{Fe}^{3+}$ and $\mathrm{F}$ was found (Table 3).

\section{THERMOBAROMETRY}

\section{Inclusions in garnet}

Phase equilibria between inclusions and their hosts may be complicated by different thermal expansivity and compressibility (Zhang, 1998). These difficulties may be circumvented by considering only formation $P$ and $T$, if the compositions of phases are preserved from the time of their formation. Inclusion assemblages chosen for thermobarometry occur close to one another in garnet. Simple inclusions are preferred to
Table 4. Representative electron microprobe analyses of amphibole $^{\mathrm{a}}$, and biotite. ${ }^{\mathrm{b}}$

\begin{tabular}{|c|c|c|c|c|c|}
\hline & 1 & 2 & 3 & 4 & 5 \\
\hline $\mathrm{SiO}_{2}$ & 42.11 & 42.30 & 47.44 & 40.80 & 37.77 \\
\hline $\mathrm{TiO}_{2}$ & 1.11 & 2.51 & 0.45 & 0.75 & 3.46 \\
\hline $\mathrm{Al}_{2} \mathrm{O}_{3}$ & 13.79 & 14.61 & 11.40 & 18.39 & 16.76 \\
\hline $\mathrm{Cr}_{2} \mathrm{O}_{3}$ & n.d. & 0.04 & n.d. & 0.09 & n.c. \\
\hline $\mathrm{Fe}_{2} \mathrm{O}_{3}$ & 5.29 & 0.73 & 5.73 & 4.84 & n.a. \\
\hline $\mathrm{FeO}$ & 9.49 & 11.81 & 7.77 & 9.78 & 15.11 \\
\hline $\mathrm{MnO}$ & 0.07 & 0.09 & 0.02 & 0.07 & 0.06 \\
\hline $\mathrm{MgO}$ & 11.61 & 11.19 & 13.11 & 9.71 & 13.17 \\
\hline $\mathrm{CaO}$ & 11.38 & 10.27 & 11.53 & 11.28 & 0.11 \\
\hline $\mathrm{Na}_{2} \mathrm{O}$ & 2.71 & 3.47 & 1.26 & 1.91 & 0.26 \\
\hline $\mathrm{K}_{2} \mathrm{O}$ & 0.30 & 1.14 & 0.35 & 1.33 & 9.13 \\
\hline F & n.d. & n.d. & n.d. & n.d. & n.d. \\
\hline $\mathrm{Cl}$ & 0.01 & 0.02 & 0.01 & 0.03 & 0.03 \\
\hline $\mathrm{H}_{2} \mathrm{O}$ & 2.04 & 2.04 & 2.11 & 2.06 & 3.96 \\
\hline Sum & 99.92 & 100.16 & 101.17 & 101.05 & 99.83 \\
\hline $\mathrm{Si}$ & 6.19 & 6.21 & 6.73 & 5.93 & 5.72 \\
\hline $\mathrm{Al}^{\mathrm{IV}}$ & 1.81 & 1.79 & 1.27 & 2.07 & 2.28 \\
\hline $\mathrm{Al}^{\mathrm{VI} .}$ & 0.57 & 0.73 & 0.64 & 1.08 & 0.71 \\
\hline $\mathrm{Ti}$ & 0.12 & 0.28 & 0.05 & 0.08 & 0.39 \\
\hline $\mathrm{Cr}$ & n.d. & $<0.01$ & n.d. & 0.01 & n.d. \\
\hline $\mathrm{Fe}^{3+}$ & 0.58 & 0.08 & 0.61 & 0.53 & n.c. \\
\hline $\mathrm{Fe}^{2+}$ & 1.17 & 1.45 & 0.92 & 1.19 & 1.91 \\
\hline $\mathrm{Mn}$ & 0.01 & 0.01 & $<0.01$ & 0.01 & 0.01 \\
\hline $\mathrm{Mg}$ & 2.54 & 2.45 & 2.77 & 2.10 & 2.97 \\
\hline $\mathrm{Ca}$ & 1.79 & 1.61 & 1.75 & 1.76 & 0.08 \\
\hline $\mathrm{Na}^{\mathrm{Ma}}$ & 0.21 & 0.39 & 0.25 & 0.24 & 0.08 \\
\hline $\mathrm{Na}^{\mathrm{A}}$. & 0.56 & 0.60 & 0.10 & 0.30 & - \\
\hline K & 0.06 & 0.21 & 0.06 & 0.25 & 1.76 \\
\hline $\mathrm{OH}$ & 2.00 & 2.00 & 2.00 & 1.99 & 3.99 \\
\hline $\mathrm{F}$ & n.d. & n.d. & n.d. & n.d. & n.d. \\
\hline $\mathrm{Cl}$ & $<0.01$ & $<0.01$ & $<0.01$ & 0.01 & 0.01 \\
\hline
\end{tabular}

${ }^{\text {a }}$ Hornblende formulae normalized to 13 small cations $\mathrm{Fe}^{2+} / \mathrm{Fe}^{3+}$ estimated by charge balance. ${ }^{\mathrm{b}}$ Biotite formula normalized to 14 small cations, all $\mathrm{Fe}$ assumed to be $\mathrm{Fe}^{2+}$ n.d. not detectable, n.c. not calculated. Detection limits for $F$ are $0.0 x$. Matrix hornblende 01LR04 [no. 1], 01 BK-05 [no. 3]. Inclusion hornblende 01LR-04 [no. 2] 01 BK-05 [no. 4]. Inclusion biotite 01LR-01b [no. 5].

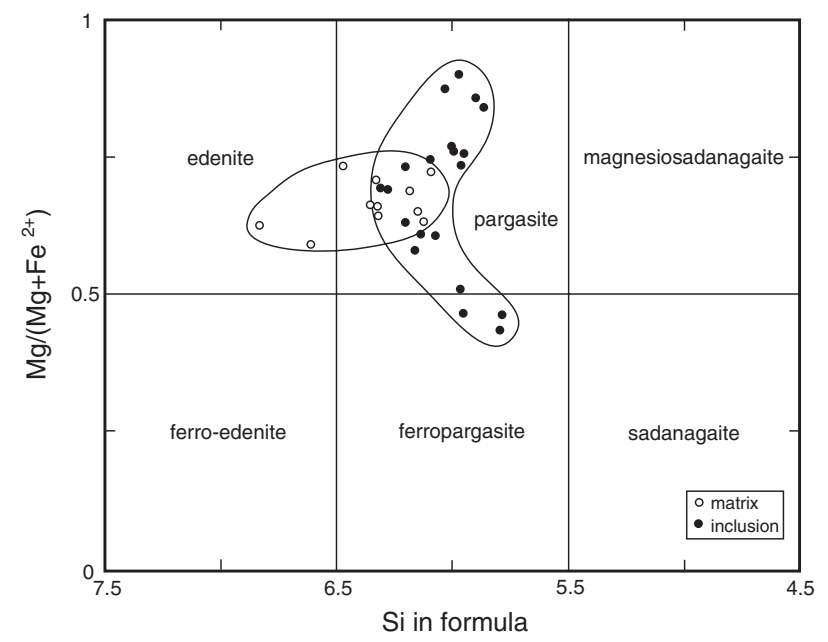

Fig. 5. Hornblende compositions classified after Leake et al. (1997)

compound inclusions, and in all cases, inclusions and the surrounding garnet are evaluated for chemical zoning.

In the case of clinopyroxene inclusions, progress of the reaction: 
Table 5. Representative electron microprobe analyses of plagioclase. $^{\mathrm{a}}$

\begin{tabular}{lccc}
\hline & 1 & 2 & 3 \\
\hline $\mathrm{SiO}_{2}$ & 60.86 & 62.01 & 61.74 \\
$\mathrm{Al}_{2} \mathrm{O}_{3}$ & 24.80 & 24.47 & 24.43 \\
$\mathrm{Fe}_{2} \mathrm{O}_{3}$ & 0.07 & 0.13 & 0.23 \\
$\mathrm{MgO}$ & n.d & n.d & n.d \\
$\mathrm{CaO}$ & 5.60 & 5.38 & 5.26 \\
$\mathrm{SrO}$ & n.d. & n.d. & n.d. \\
$\mathrm{BaO}$ & n.d. & n.d. & n.d. \\
$\mathrm{Na}{ }_{2} \mathrm{O}$ & 8.73 & 8.75 & 8.64 \\
$\mathrm{~K}_{2} \mathrm{O}$ & 0.04 & 0.06 & 0.06 \\
$\mathrm{Total}$ & 100.09 & 100.79 & 100.36 \\
$\mathrm{Si}$ & 2.70 & 2.73 & 2.73 \\
$\mathrm{Al}$ & 1.30 & 1.27 & 1.27 \\
$\mathrm{Fe}$ & $<0$. & 0.01 & 0.01 \\
$\mathrm{Ba}$ & 0.01 & n.d. & n.d. \\
$\mathrm{Ca}$ & n.d. & 0.25 & 0.25 \\
$\mathrm{Sr}$ & 0.27 & n.d. & n.d. \\
$\mathrm{Na}$ & n.d. & 0.75 & 0.74 \\
$\mathrm{~K}$ & 0.75 & $<0.01$ & 0.01 \\
$\mathrm{X}_{\mathrm{Ab}}$ & $<0.01$ & 0.74 & 0.75 \\
$\mathrm{X}_{\mathrm{An}}$ & 0.74 & 0.25 & 0.25 \\
$\mathrm{X}_{\mathrm{Or}}$ & 0.26 & 0.00 & 0.00 \\
\hline & 0.00 & & \\
\hline $\mathrm{For}$ & & &
\end{tabular}

${ }^{\text {a }}$ Formulae normalized to 8 oxygen; n.d. not detected. Plagioclase symplectite with diopside and hypersthene: 99BK-02 [no. 1]. Plagioclase symplectite with diopside: 99LR-02 [no. 2]. Plagioclase rimming garnet: 01BK-04 [no. 3].

$$
\begin{gathered}
\text { Ca-Tschermak's + diopside } \\
=\text { grossular }+ \text { pyrope }
\end{gathered}
$$

may occur in either direction after formation of the pyroxene. However, the lack of fracturing around many inclusions coupled with minimal zoning in the garnet surrounding them can be taken as evidence that no net transfer reaction has taken place. This cannot be said for exchange reactions, which may have re-equilibrated during the retrograde path, leaving no textural evidence.

Exchange thermometry $\left(\mathrm{Fe}^{2+} / \mathrm{Mg}\right)$ was undertaken on inclusions of clinopyroxene and hornblende with their host garnet. Clinopyroxene-garnet pairs yield temperatures of $530-600{ }^{\circ} \mathrm{C}$ using the thermometer of Krogh Ravna (2000a), and hornblende-garnet pairs yield temperatures of $520-650{ }^{\circ} \mathrm{C}$ with the thermometer of Krogh Ravna (2000b). It is possible that these mineral pairs reflect retrograde temperatures due to diffusional exchange of $\mathrm{Fe}^{2+} / \mathrm{Mg}$.

A number of garnet contain inclusion assemblages of rutile, epidote, titanite and quartz, which allows the application of the reaction of Manning \& Bohlen (1991):

$$
\begin{aligned}
& 2 \text { clinozoisite }+5 \text { titanite } \\
& \quad=3 \text { grossular }+5 \text { rutile }+2 \text { quartz }+\mathrm{H}_{2} \mathrm{O}
\end{aligned}
$$

The activities of $\mathrm{CaTiSiO}_{5}$ in titanite and $\mathrm{TiO}_{2}$ in rutile were calculated assuming ideal molecular mixing models (Essene, 1989). The activity of $\mathrm{Ca}_{2} \mathrm{Al}_{3-}$ $\mathrm{Si}_{3} \mathrm{O}_{12}(\mathrm{OH})$ in epidote was calculated using the $\mathrm{A} / \mathrm{X}$ program of Holland \& Powell. The $\mathrm{Ca}_{3} \mathrm{Al}_{2} \mathrm{Si}_{3} \mathrm{O}_{12}$ activity in garnet was calculated using the quaternary mixing model of Ganguly et al. (1996). The locus of reaction (2) was calculated using the computer program THERMOCALC v. 3.1 using the 1998 thermodynamic database (Holland \& Powell, 1998), and yields pressures of $6-10 \mathrm{kbar}$ over $400-600^{\circ} \mathrm{C}$ in sample 99BK-01 and 8-12 kbar over $450-675^{\circ} \mathrm{C}$ in sample 99LR-01 (Fig. 6). The temperature limits for this barometer are provided by reactions on the stability of clinozoisite (Perkins et al., 1980; Newton, 1966):

$$
\begin{aligned}
& \text { grossular }+5 \text { lawsonite } \\
& \quad=4 \text { clinozoisite }+ \text { quartz }+8 \mathrm{H}_{2} \mathrm{O} \\
& 4 \text { clinozoisite }+ \text { quartz } \\
& \quad=\text { grossular }+5 \text { anorthite }+2 \mathrm{H}_{2} \mathrm{O}
\end{aligned}
$$

The loci of reactions (3) and (4) were calculated using THERMOCALC with unit activities for the absent phases (lawsonite, anorthite and $\mathrm{H}_{2} \mathrm{O}$ ), and constrain the temperature range of these inclusions to between 400 and $675{ }^{\circ} \mathrm{C}$ (Fig. 6). These conditions are at or below the inferred peak pressure and temperature and further suggest that the inclusion assemblage was entrapped during the prograde growth history of the garnet.

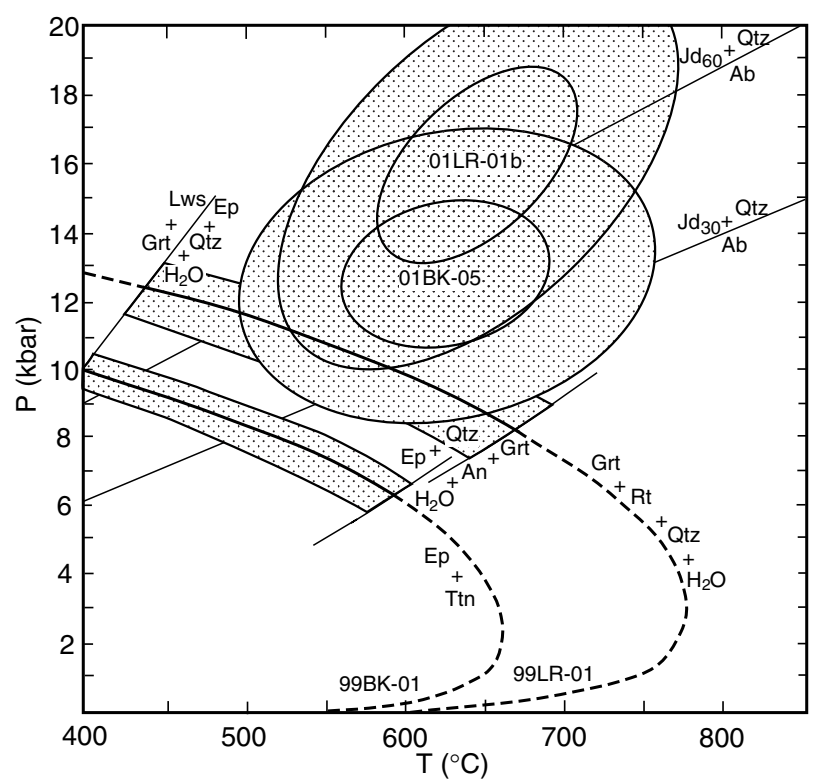

Fig. 6. Possible prograde reactions. Reaction $2(\mathrm{Ep}+\mathrm{Ttn}=$ $\mathrm{Grt}+\mathrm{Rt}+\mathrm{Qtz}+\mathrm{H}_{2} \mathrm{O}$ ) is plotted for samples 99BK-01 and 99LR-01, and is metastable where dashed. The stippled region around each curve is the error in the reaction calculated from the $2 \sigma$ counting error for $\mathrm{Ca}$ in garnet, likely the largest source of error in the calculation. The inclusion $P-T$ conditions are bound along the curve for reaction 2 by the stability of epidote. The ellipses are average pressure-temperature calculations based on reactions 5-8 for biotite bearing samples $01 \mathrm{LR}-01 \mathrm{~b}$ and $01 \mathrm{BK}-05$. The black ellipse represents $1 \sigma$ error from the leastsquares calculation, stippled pattern, $2 \sigma$. Eclogite facies pressure minima given by reaction 10 are plotted for the most jadeite rich composition in this study $\left(\mathrm{Jd}_{30}\right)$, and that reported in Lee et al. $(2001)\left(\mathrm{Jd}_{60}\right)$. 
Biotite and amphibole also occur as inclusions in garnet. The Holland \& Powell A/X program was used to calculate activities for end-member amphibole, garnet and biotite, and THERMOCALC was used to balance the following four equilibria:

$$
\begin{aligned}
& 12 \text { tremolite }+13 \text { annite }+21 \text { eastonite } \\
& =13 \text { almandine }+8 \text { grossular } \\
& +34 \text { phlogopite }+12 \text { quartz }+12 \mathrm{H}_{2} \mathrm{O} \\
& 42 \text { pargasite }+114 \text { quartz } \\
& =20 \text { pyrope }+22 \text { grossular }+9 \text { tremolite } \\
& +21 \text { glaucophane }+12 \mathrm{H}_{2} \mathrm{O} \\
& 2 \text { pyrope }+4 \text { grossular }+3 \text { tremolite } \\
& +3 \text { tschermakite }+6 \text { glaucophane } \\
& =12 \text { pargasite }+36 \text { quartz } \\
& \text { almandine }+2 \text { grossular }+3 \text { tremolite } \\
& +3 \text { glaucophane }+3 \text { eastonite } \\
& =6 \text { pargasite }+2 \text { phlogopite } \\
& + \text { annite }+18 \text { quartz }
\end{aligned}
$$

Reactions (5) and (6) involve dehydration, and (7) and (8) are solid-solid reactions. All but (5) include a glaucophane component that is low and likely to be rather uncertain in hornblende. Average $P-T$ intersections of these reactions were calculated using THERMOCALC and found to be at 13-16 kbar and 630$660{ }^{\circ} \mathrm{C}$ with the activity of $\mathrm{H}_{2} \mathrm{O}$ assumed to be unity (Fig. 6). If the activity of $\mathrm{H}_{2} \mathrm{O}$ in the fluid is reduced to 0.5 , average $P-T$ are reduced by approximately 0.5 kbar and $20^{\circ} \mathrm{C}$, respectively.

The variable $\mathrm{K}$ content of included vs. matrix hornblende also suggest different $P-T$ conditions during their formation. Amphibole rich in K-richterite, $\mathrm{KNaCaMg}_{5} \mathrm{Si}_{8} \mathrm{O}_{22}(\mathrm{OH})_{2}$, have been inferred to require pressures in the range of 60-80 kbar (Konzett et al., 1997; Konzett \& Ulmer, 1999). Konzett obtained unreversed experiments in the KNCMASH system on the reaction:

$$
\begin{aligned}
& 2 \text { K-richterite }+ \text { pyrope }=\text { phlogopite } \\
& +2 \text { diopside }+2 \text { jadeite }+5 \text { enstatite }
\end{aligned}
$$

Thus, it is the assemblage K-richterite-pyrope that requires the 60-80 kbar, not K-richterite by itself. Reaction (9) is applicable as a lower pressure limit to the inclusion assemblage: hornblende-biotite-garnetpyroxene in the absence of orthopyroxene. Calculations of the locus of this reaction based on the experiments of Konzett \& Ulmer (1999) and corrected for observed solid solutions yield pressure minima of $35-37 \mathrm{kbar}$ at $700{ }^{\circ} \mathrm{C}$. It is unlikely that these eclogites ever reached such pressures in the absence of evidence for former coesite inclusions in the garnet. The cause of the erroneous barometry using reaction (9) is not known. Reversed experiments in Fe-bearing systems and determination of the thermodynamic properties of K-richterite may make reaction (9) more useful in the barometry of rocks with garnet and K-bearing amphibole.

\section{Eclogite facies assemblage}

Temperatures in eclogites are usually derived from the $\mathrm{Fe}^{2+} / \mathrm{Mg}$ exchange reaction between clinopyroxene and garnet. Given the textural complexity of the Bakersville eclogites it is difficult to determine which matrix pyroxene composition is in equilibrium with which garnet composition. If the sodic clinopyroxene cores are assumed to be in equilibrium with the garnet cores, the garnet/clinopyroxene thermometer of Krogh Ravna (2000a) gives temperatures of approximately $700{ }^{\circ} \mathrm{C}$, and $800-900{ }^{\circ} \mathrm{C}$ neglecting $\mathrm{Fe}^{3+}$.

The reaction (Holland, 1980, 1983):

$$
\text { albite }=\text { jadeite }+ \text { quartz }
$$

is conventionally used to calculate a lower pressure limit in eclogites. In the absence of plagioclase equilibrated with pyroxene, the locus of the reaction is calculated with a unit activity for albite. The activity of $\mathrm{NaAlSi}_{2} \mathrm{O}_{6}$ in clinopyroxene was calculated using the model of Anovitz (1991). The locus of the end-member reaction was calculated with THERMOCALC, and yields minimum pressures of 9-13 kbar in the temperature range of $600-800{ }^{\circ} \mathrm{C}$. Willard \& Adams (1994) combined the texturally late plagioclase with the earlier clinopyroxene and obtained 13-17 kbar. Lee et al. (2001) found rare cores of $\mathrm{Jd}_{60}$ in some of the matrix pyroxene from the same localities as the present study. They calculated minimum pressures of 14-16 kbar at $730-790{ }^{\circ} \mathrm{C}$ from their data, about 2 kbar less than reaction (10) calculated here using THERMOCALC with $a\left(\mathrm{NaAlSi}_{2} \mathrm{O}_{6}\right)=0.60$. All these pressures must be regarded as minima in the absence of plagioclase equilibrated with the assemblage.

\section{Retrograde assemblages}

The presence of hypersthene intergrown with the plagioclase-diopside symplectite suggests retrogression through the granulite facies. Clinopyroxene-orthopyroxene solvus thermometry using the program QUILF (Andersen et al., 1993) gives a temperature of $740 \pm 50{ }^{\circ} \mathrm{C}$ for the coexisting pyroxenes. Garnet zoning suggests that the more Fe-rich and $\mathrm{Mg}$-poor rims equilibrated with a matrix ferromagnesian phase at lower temperature than the peak temperature. If the highest $\mathrm{Mg}$ content region of the garnet (just inside the retrograde rim) is taken to be in equilibrium with the diopside/plagioclase symplectite after omphacite, the garnet-anorthite-diopside/hedenbergite-quartz (GADS/GAHS) and garnet-anorthiteenstatite/ferrosilite-quartz (GAES/GAFS) barometers can be applied (Moecher et al., 1988). The loci of these 
univariant reactions calculated using THERMOCALC give pressures that yield 10-11 kbar (GAFS) and 15-16 kbar (GAHS) over the temperature range given by pyroxene solvus thermometry (Fig. 7). The clinopyroxene barometers (GADS/GAHS) intersect at lower temperatures, giving $620^{\circ} \mathrm{C}$ at $13 \mathrm{kbar}$. The orthopyroxene barometers (GAES/GAFS) intersect at $>1000{ }^{\circ} \mathrm{C}$.

Assuming that the garnet rim compositions re-equilibrated with matrix hornblende, the $\mathrm{Fe}^{2+} / \mathrm{Mg}$ exchange thermometer of Krogh Ravna (2000b) yields $500-550{ }^{\circ} \mathrm{C}$. If no estimate of ferric iron is made and all $\mathrm{Fe}$ is assumed to be $\mathrm{Fe}^{2+}$, then temperatures increase by approximately $100{ }^{\circ} \mathrm{C}$. Barometry of the hornblende-plagioclase-garnet rim assemblage was applied using the reactions (Kohn \& Spear, 1989, 1990):

$$
\begin{aligned}
& 6 \text { anorthite }+3 \text { albite }+3 \text { tremolite } \\
& =2 \text { grossular }+ \text { pyrope }+3 \text { pargasite } \\
& \quad+18 \text { quartz }
\end{aligned}
$$

6 anorthite +3 tremolite $=2$ grossular

$$
+ \text { pyrope }+3 \text { tschermakite }+6 \text { quartz }
$$

These reactions were calculated using thermocalc, and give $9-12 \mathrm{kbar}$ for temperatures of $500-550{ }^{\circ} \mathrm{C}$ (Fig. 7).

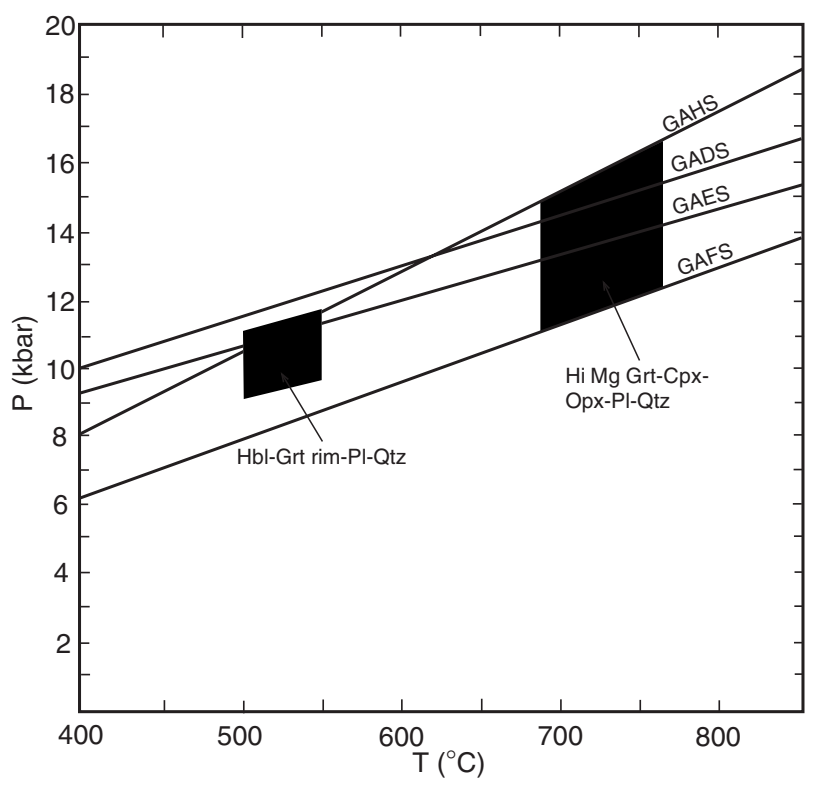

Fig. 7. Pressure-temperature phase diagram for retrograde assemblages. The granulite facies assemblage is constrained by the GADS, GAHS, GAFS, and GAES barometers and twopyroxene thermometry. The amphibolite facies assemblage is constrained by garnet - hornblende - plagioclase barometry and garnet - hornblende thermometry.

\section{DISCUSSION}

The high variance of the peak eclogitic assemblage in the Bakersville rocks presents the same difficulties as those typically experienced in the thermobarometry of other eclogites world-wide. The presence of a greater diversity of minerals in the prograde and retrograde assemblages allows us to better constrain those stages of the metamorphic history.

\section{Prograde equilibria}

Temperature estimates from $\mathrm{Fe}^{2+} / \mathrm{Mg}$ exchange thermometry between inclusion and host phases can be complicated in rocks with multiple stages of metamorphism because of diffusion of the cations. Included clinopyroxene and hornblende differ chemically from their matrix counterparts. Temperatures from these inclusions paired with their host garnet give a range of $520-650^{\circ} \mathrm{C}$. These inclusions are not zoned, although some unzoned inclusions in garnet exchange $\mathrm{Fe}^{2+} / \mathrm{Mg}$ with their host, leaving a halo of $\mathrm{Fe}^{2+} / \mathrm{Mg}$ zoning in the surrounding garnet host (Wang et al., 1999). Detailed microprobe traverses around these inclusions fail to reveal any such haloes at the scale of the EMP analyses. This presents several possibilities: (1) the inclusions have not re-equilibrated with the garnet, and record their temperature of formation; (2) the inclusions are small enough in volume so that the re-equilibration haloes are below the resolution of a microprobe traverse; (3) the time involved for prograde metamorphism in the North Carolina eclogites was much more rapid than the cooling of mantle garnet of Wang et al. (1999); or (4) the prograde halo was largely removed during retrograde resetting. Wang et al. (1999) noted that halo width decreases markedly with inclusion size, and these inclusions are, in general, an order of magnitude smaller than those of that study. Although the temperatures recorded by the clinopyroxene and hornblende inclusions seem reasonable for prograde formation, and overlap with other prograde temperature constraints, there is a possibility that they were reset during the retrograde path.

Reaction (2) provides a thermobarometer for the inclusion assemblage epidote-titanite-garnet-rutilequartz. Although the temperature range provided by reactions (3) and (4) is fairly large, they clearly constrain the pressure and temperature (6-10 kbar, 400$600{ }^{\circ} \mathrm{C}$ and $8-12 \mathrm{kbar}, 450-680{ }^{\circ} \mathrm{C}$ ) to less than those at or near the peak of metamorphism. The different loci of this reaction for different sets of inclusion assemblages may be due to each set recording different points on the prograde path (Fig. 6). Although these data seem reasonable, they are disparate with the pressures and temperatures given by biotitehornblende-garnet reactions. The biotite-hornblendegarnet-quartz assemblage is within the range of possible peak pressures and temperatures (13-16 kbar, $630-660{ }^{\circ} \mathrm{C}$ ) for the eclogite assemblage. Reactions 
that constrain the formation conditions of this assemblage make use of model-dependant amphibole end-members (such as glaucophane) with low and rather uncertain activity in these hornblende compositions. This model dependence and low activity may introduce significant error into these calculations.

The inclusion assemblages: epidote-titanite-rutilegarnet-quartz and epidote-hornblende-biotite-garnet-quartz do not occur in the same garnet. It is possible that the various garnet that have entrapped these different assemblages (recording different pressures and temperatures) grew at different periods during the prograde history of the rock.

\section{Eclogite stage}

Temperature in eclogites is usually derived from the $\mathrm{Fe}^{2+} / \mathrm{Mg}$ exchange reaction between clinopyroxene and garnet. Beyond the possible pitfall of using empirical thermometers not calibrated for ordering in omphacite (Essene, 1982, 1989), the textural complexity and retrograde overprinting of these rocks makes it difficult to determine which clinopyroxene composition is in equilibrium with which garnet composition. The original temperature estimate for these rocks (630$790{ }^{\circ} \mathrm{C}$ ) was calculated based on $\mathrm{Fe}^{2+} / \mathrm{Mg}$ exchange pairing garnet core with pyroxene core, and garnet rim with pyroxene rim (Willard \& Adams, 1994). These temperatures are slightly higher than those calculated in this study, which are approximately $700{ }^{\circ} \mathrm{C}$ for cores and $500-600{ }^{\circ} \mathrm{C}$ for rims.

The only constraints on the peak pressure conditions are the minimum pressure $\left(10-13 \mathrm{kbar}\right.$ at $\left.600-790{ }^{\circ} \mathrm{C}\right)$ given by reaction (10), and a maximum pressure of 28 29 kbar given by the absence of coesite over the same temperature interval (Bohlen \& Boettcher, 1982). The locus of reaction (10) was calculated using pure albite in the absence of plagioclase in textural equilibrium, yielding minimum pressures if $c .3 \mathrm{kbar}$ lower than those calculated by Willard \& Adams (1994). They used the diluted albite of the retrograde plagioclase, which shifts the locus of the univariant curve to higher pressures. This practice is questionable, because textures clearly indicate that the retrograde plagioclase equilibrated with the late diopsidic pyroxene and not with the earlier omphacitic pyroxene. In any case, the thermobarometric limits for the eclogitic stage of this study do not greatly differ with that of Willard \& Adams (1994).

\section{Retrograde evolution}

The presence of hypersthene in the retrograde diopside-plagioclase assemblage is evidence for high temperature $\left(750{ }^{\circ} \mathrm{C}\right)$ retrogression through the granulite facies. Barometry of this assemblage suggests that the Bakersville rocks were still at high pressures when they passed into the granulite facies. If the temperature estimates for the eclogite stage of metamorphism are valid, then the Bakersville rocks may have passed through the granulite facies either by slight isothermal decompression or by decompression with some heating (Fig. 8).

Willard \& Adams (1994) suggested relatively high temperature retrogression in the amphibolite facies (8.5-12 kbar and $650-730{ }^{\circ} \mathrm{C}$ ) by applying garnethornblende thermometry (Graham \& Powell, 1984) and garnet-hornblende-plagioclase-quartz barometry (Moecher et al., 1988; Kohn \& Spear, 1990). Their pressures are consistent with those calculated in this study for the same assemblage, although the temperatures of this study are $100-200^{\circ}$ lower, probably due to the effect of the neglected ferric iron in hornblende on the equilibria.

The data of this study suggest a clockwise $P-T$ path (Fig. 8). Pressures and temperatures in the prograde path are constrained by inclusion assemblages in the garnet. Peak pressure and temperature are constrained by the albite-jadeite-quartz (reaction 10) minimum. The biotite inclusion assemblage records pressure and temperature above reaction (10). Although this may be the peak pressure of metamorphism, it seems more likely that the biotite and hornblende inclusions formed during the late prograde stage albeit above the matrix pressure minimum. Early retrogression of these

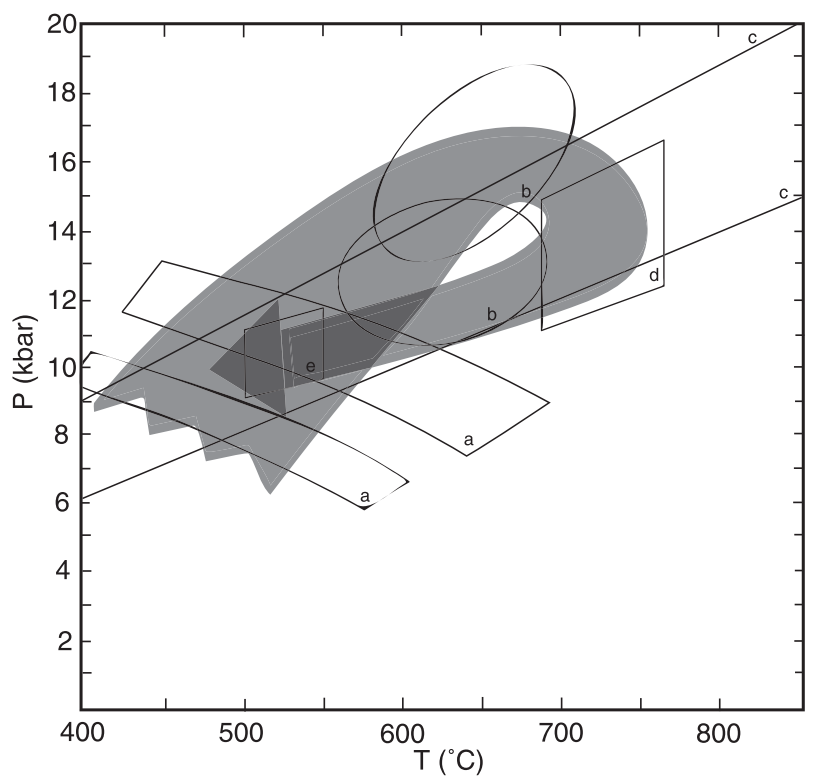

Fig. 8. Possible $P-T$ path of the Bakersville eclogite. Prograde evolution is constrained by inclusion Thermobarometry using reaction 2 (a) and reactions 5-8 (b). The peak of metamorphism is constrained only by minimum $P$ from reaction 10 (c), and thus the path could extend to higher $P-T$. The path then passes through the $P-T$ constrained by GADS/GAHS/GAES/GAFS barometry and two pyroxene thermometry (d). Finally the path passes through the amphibolite facies assemblage constrained by garnet-rim/hornblende thermometry and garnet rim - hornblende - plagioclase barometry (e). A double loop configuration is also possible, with the late amphibolite representing a separate pulse of metamorphism from the Acadian Orogeny. 
rocks passed through the granulite facies either by isothermal decompression, or decompression coupled with heating, depending on the peak temperature, which is poorly constrained. The amphibolite facies overprint of 9-12 kbar at $500-550{ }^{\circ} \mathrm{C}$ may represent continued cooling with a slight decrease in pressure (Fig. 8), or may be the result of a separate pulse of later metamorphism (Miller et al., 2000).

\section{Tectonic Interpretation}

The North Carolinian eclogites have been interpreted as pieces of oceanic crust subducted as the Piedmont terrane approached the Laurentian margin (Willard \& Adams, 1994; Adams et al., 1995). This oceanic crust may be that of Iapetus, or a forearc basin on the Laurentian margin (Hatcher, 2001). Upon subduction to depths necessary for eclogite formation $(=50 \mathrm{~km})$, thrusting caused by the collision of the Piedmont terrane and Laurentia uplifted the eclogite and its metasedimentary host (the Ashe Metamorphic Suite, AMS). Willard \& Adams (1994) calculated peak conditions of $6-8 \mathrm{kbar}$ and $580-640^{\circ} \mathrm{C}$ in the AMS schist adjacent to the eclogite. It is unclear how the eclogite was entrained in the lower grade Ashe Suite schists; Stewart et al. (1997) discussed various mechanisms, including the entrainment of eclogite pods in upward flowing material, similar to the model by Cloos (1982) for the Franciscan of California. They noted, however, that size of the Bakersville eclogite pods might limit the applicability of that model.

Alternatively, the AMS and equivalent units to the south have been interpreted as metamorphosed riftrelated sediments (Hatcher, 1987), rather than an accretionary mélange (Abbott \& Raymond, 1984). Stewart \& Miller (2001) discussed the possibility that the eclogite might be the product of deep underthrusting during collision, but noted that the AMS should also have been metamorphosed to high-pressure conditions. AMS equivalent rocks at Winding Stair Gap, North Carolina, have yielded peak conditions of $850-900{ }^{\circ} \mathrm{C}$ at $9-10 \mathrm{kbar}$ (Moecher, 2000). A detailed examination of the $P-T$ history of the Ashe Metamorphic Suite is warranted to determine if it endured similar high-pressure conditions that were partially obscured by later metamorphic events.

If the eclogite was formed by the subduction of oceanic crust, then the prograde path may be that of a subducting slab. The prograde conditions recorded in these rocks require that the geothermal gradient be greater than $35-40{ }^{\circ} \mathrm{C} \mathrm{kbar}{ }^{-1}\left(c .11-12{ }^{\circ} \mathrm{C} \mathrm{km}^{-1}\right)$ if the eclogite protolith followed a continuous path from near-surface conditions to peak pressure. This gradient is consistent with a relatively 'hot' subduction path. Hot gradients in subduction zones can be caused by a variety of parameters, including: the young age of the subducting crust, heat from the upper plate of a young subduction zone, or slow subduction rate (Cloos, 1985; Peacock, 1987). This relatively shallow, hot gradient seems more consistent with the subduction of a small, young marginal basin coupled with continental collision than the prolonged subduction of a wider, more thermally mature oceanic plate.

Blueschists and eclogites from long-lived subduction zones without evidence of continental collision (e.g. the Franciscan), are often characterized by retrograde paths that are similar to the prograde history. In contrast, high pressure metamorphic rocks from continental collision zones, with no 'refrigeration' from a continuously downgoing slab, show evidence for higher temperature retrogression (Ernst, 1988). The presence of high-pressure granulite overprints on eclogites has been the subject of much recent study: O'Brien \& Rötzler (2003) review this subset of highpressure granulites and describe them as the products of subduction without the rapid exhumation necessary to preserve pristine eclogite. The eclogites in this study follow a retrograde path through the high-pressure granulite facies closely similar to other eclogites found in collisional zones (e.g. O'Brien \& Rötzler, 2003 and references therein).

The age estimate of peak metamorphism for these eclogites is $461 \pm 4 \mathrm{Ma}$ by $\mathrm{U}-\mathrm{Pb}$ ion probe data on zircon (Miller et al., 2000), which has been refined to $459.0+1.5 /-0.6$ Ma by ID-TIMS (B. V. Miller, Pers. Comm.). This age is closely similar to other Taconic metamorphic ages in the Eastern Blue Ridge, including the $458 \pm 0.9 \mathrm{Ma}$ highest-grade granulite facies metasediments at Winding Stair Gap. In order to support the Franciscan style subduction model, Stewart \& Miller (2001) suggested that the eclogite might have formed during subduction to the north of its present location, where the Taconian collision occurred later than in the southern Appalacians. Significant strike-slip faulting along the Acadian Burnsville fault later moved the eclogite to its present position. If the eclogite was formed by underthrusting during the Taconian collision, there is no need for a complex structural justification. The shallow 'hot' prograde path and granulite facies overprint of these eclogites, coupled with their formation during the peak of Taconic metamorphism in the southern Appalachians, suggests that these rocks are the product of deep underthrusting during continental collision.

Miller et al. (2000) interpreted $420 \pm 15 \mathrm{Ma}$ zircon rims and a $393 \pm 1 \mathrm{Ma} \mathrm{U}-\mathrm{Pb}$ titanite age as an Acadian amphibolite facies event, and a $\mathrm{U}-\mathrm{Pb}$ rutile age of $333.7 \pm 0.4 \mathrm{Ma}$ as recording final cooling. Our $P-T$ loop as drawn in Fig. 8, includes the amphibolite facies retrogression as continued cooling from a single metamorphic event. A double loop scenario, wherein the eclogites decompress after the granulite facies and are remetamorphosed to amphibolite facies during the Acadian Orogeny, is also possible. 


\section{ACKNOWLEDGEMENTS}

This work was supported by grant EAR 00-87448 from the National Science Foundation to EJE and SBM, and by the Turner Fund of the Department of Geological Sciences at the University of Michigan to FZP. We thank K. G. Stewart, M. G. Adams, and J. Kollmeier for their help in the field, and C. W. Carrigan and B. V. Miller for insightful discussions on North Carolina geology. Thanks also to J. A. Gilotti and E.D. Ghent for their careful reviews which greatly improved this manuscript. The authors are grateful to C. E. Henderson for his invaluable assistance with the electron microprobe and SEM. The electron microprobes used in this work were acquired under EAR 8212764 and 99-11352, and the scanning electron microscope under EAR 96-28196 from the National Science Foundation.

\section{REFERENCES}

Abbott, R. N. \& Greenwood, J. P., 2001. Retrograde metamorphism of eclogite in the southern Appalachian Mountains, U.S.A.: a case involving seamount subduction? Journal of Metamorphic Geology, 19, 433-443.

Abbott, R. N. \& Raymond, L. A., 1984. The Ashe Metamorphic Suite, northwest North Carolina: metamorphism and observations on geologic history. American Journal of Science, 284, 350-375.

Adams, M. G., Stewart, K. G., Trupe, C. H. \& Willard, R. A., 1995. Tectonic significance of high-pressure metamorphic rocks and dextral strike-slip faulting along the Taconic Suture. In: Current Perspectives in the Appalachian-Caledonian Orogen (eds Hibbard, J. P., van Staal, C. R. \& Cawood, P. A.), pp. 21-42. Geological Association of Canada, Toronto.

Adams, M. G. \& Trupe, C. H., 1997. Conditions and timing of metamorphism in the Blue Ridge thrust complex, northwestern North Carolina and eastern Tennessee. In: Paleozoic Structure, Metamorphism, and Tectonics of the Blue Ridge of Western North Carolina, Carolina Geological Society Field Trip and Annual Meeting (eds Stewart, K. G., Adams, M. G. \& Trupe, C. H.), pp. 33-48. Carolina Geological Society, Banner Elk, NC.

Andersen, D. J., Lindsley, D. H. \& Davidson, P. M., 1993. QUILF; a Pascal program to assess equilibria among Fe-MgMn-Ti oxides, pyroxenes, olivine, and quartz. Computers and Geosciences, 19, 1333-1350.

Anovitz, L. M., 1991. Al zoning in pyroxene and plagioclase; window on late prograde to early retrograde P-T paths in granulite terranes. American Mineralogist, 76, 1328-1343.

Bohlen, S. R. \& Boettcher, A. L., 1982. The quartz $\leftrightarrow$ coesite transformation: a precise determination and the effects of other components. Journal of Geophysical Research B, 87, 7073-7078.

Bream, B. R., Hatcher, R. D., Miller, C. F., Carrigan, C. W. \& Fullagar, P. D., 2001. Provenance and geochemistry of late Proterozoic Southern Appalachian crystalline core paragneisses, NC-SC-GA-TN. Geological Society of America Abstracts with Programs, 33, 29.

Carrigan, C. W., Miller, C. F., Fullagar, P. D., Bream, B. R., Hatcher, R. D. \& Coath, C. D., 2003. Ion microprobe age and geochemistry of southern Appalachian basement, with implications for Proterozoic and Paleozoic reconstructions. Precambrian Research, 120, 1-36.

Carswell, D. A., 1990. Eclogite Facies Rocks, Blackie and Son, Glasgow.
Chinner, G. A. \& Dixon, J. E., 1973. Some high-pressure paragenesis of the Allalin Gabbro, Valais, Switzerland. Journal of Petrology, 14, 185-202.

Chopin, C., 1984. Coesite and pure pyrope in high-grade blueschists of the Western Alps: a first record and some consequences. Contributions to Mineralogy and Petrology, 86, $107-118$

Cloos, M., 1982. Flow melanges: numerical modeling and geologic constraints on their origin in the Franciscan subduction complex, California. Geological Society of America Bulletin, 93, 330-344.

Cloos, M., 1985. Thermal evolution of convergent plate margins: thermal modeling and reevaluation of isotopic Ar-ages for blueschists in the Franciscan Complex of California. Tectonics, 4, 421-433.

Cox, R. A. \& Indares, A., 1999. Transformation of Fe-Ti gabbro to coronite, eclogite and amphibolite in the Baie du Nord segment, Manicouagan imbricate zone, eastern Grenville Province. Journal of Metamorphic Geology, 17, 537-555.

Dachs, E. \& Proyer, A., 2001. Relics of high-pressure metamorphism from the Grossglockner region, Hohe Tauern, Austria; paragenetic evolution and PT-paths of retrogressed eclogites. European Journal of Mineralogy, 13, 67-86.

Elvevold, S. \& Gilotti, J. A., 2000. Pressure-temperature evolution of retrogressed kyanite eclogites, Weinschenk Island, North-East Greenland Caledonides. Lithos, 53, 127-147.

Enami, M. \& Nagasaki, A., 1999. Prograde P-T path of kyanite eclogites from Junan in the Sulu ultrahigh-pressure province, eastern China. Island Arc, 8, 459-474.

Ernst, W. G., 1988. Tectonic history of subduction zones inferred from retrograde blueschist P-T paths. Geology, 16, 1081-1084.

Essene, E. J., 1982. Geologic thermometry and barometry. Characterization of metamorphism through mineral equilibria, Reviews in Mineralogy, 10, 153-206.

Essene, E. J., 1989. The current status of thermobarometry in metamorphic rocks. In: Evolution of Metamorphic Belts. Geological Society Special Publication 43 (eds Daly, J. S., Cliff, R. A. \& Yardley, B. W. D.), pp. 1-44. Geological Society of London, London.

Franceschelli, M., Eltrudis, A., Memmi, I., Palmeri, R. \& Carcangiu, G., 1998. Multi-stage metamorphic re-equilibration in eclogitic rocks from the Hercynian basement of NE Sardinia (Italy). Mineralogy and Petrology, 62, 167-193.

Ganguly, J., Cheng, W. \& Tirone, M., 1996. Thermodynamics of aluminosilicate garnet solid solution: new experimental data, an optimized model, and thermometry applications. Contributions to Mineralogy and Petrology, 126, 137-151.

Graham, C. M. \& Powell, R., 1984. A garnet-hornblende geothermometer: calibration, testing, and application to the Pelona Schist, Southern California. Journal of Metamorphic Geology, 2, 13-31.

Hatcher, R. D., 1987. Tectonics of the southern and central Appalachian internides. Annual Reviews of Earth and Planetary Sciences, 15, 337-362.

Hatcher, R. D., 2001. Terranes and terrane accretion in the southern Appalachians: an evolved working hypothesis. Geological Society of America Abstracts with Programs, 33, 65.

Holland, T. J. B., 1980. The reaction albite $=$ jadeite + quartz determined experimentally in the range 600-1200 degrees C. American Mineralogist, 65, 129-134.

Holland, T. J. B., 1983. The experimental determination of activities in disordered and short-range ordered jadeitic pyroxenes. Contributions to Mineralogy and Petrology, 82, 214-220.

Holland, T. J. B. \& Powell, R., 1998. An internally consistent thermodynamic data set for phases of petrological interest. Journal of Metamorphic Geology, 16, 309-343.

Kohn, M. J. \& Spear, F. S., 1989. Empirical calibration of geobarometers for the assemblage garnet + plagioclase + quartz. American Mineralogist, 74, 77-84. 
Kohn, M. J. \& Spear, F. S., 1990. Two new geobarometers for garnet amphibolites, with applications to southeastern Vermont. American Mineralogist, 75, 89-96.

Konzett, J., Sweeney, R. J., Thompson, A. B. \& Ulmer, P., 1997. Potassium amphibole stability in the upper mantle; an experimental study in a peralkaline KNCMASH system to 8.5 GPa. Journal of Petrology, 38, 537-568.

Konzett, J. \& Ulmer, P., 1999. The stability of hydrous potassic phases in lherzolite mantle; an experimental study to $9.5 \mathrm{GPa}$ in simplified and natural bulk compositions. Journal of Petrology, 40, 629-652.

Krogh Ravna, E., 2000a. The garnet-clinopyroxene $\mathrm{Fe}^{2+}-\mathrm{Mg}$ geothermometer; an updated calibration. Journal of Metamorphic Geology, 18, 211-219.

Krogh Ravna, E. J., 2000b. Distribution of $\mathrm{Fe}^{2+}$ and $\mathrm{Mg}$ between coexisting garnet and hornblende in synthetic and natural systems: an empirical calibration of the garnet-hornblende Fe-Mg geothermometer. Lithos, 53, 265-277.

Krogh, E. J., 1982. Metamorphic evolution of Norwegian country-rock eclogites, as deduced from mineral inclusions and compositional zoning in garnets. Lithos, 15, 305-321.

Krogh, E. J., Oh, C. W. \& Liou, J. G., 1994. Polyphase and anticlockwise P-T evolution for Franciscan eclogites and blueschists from Jenner, California, USA. Journal of Metamorphic Geology, 12, 121-134.

Leake, B. E., Woolley, A. R., Arps, C. E. S. et al., 1997. Nomenclature of amphiboles: Report of the Subcommittee on Amphiboles of the International Mineralogical Association, Commission on New Minerals and Mineral Names. American Mineralogist, 82, 1019-1037.

Lee, A., Whitney, D. \& Stewart, K., 2001. Petrologic study of zoned minerals to determine the P-T history of the Blue Ridge eclogites, S. Appalachians. Geological Society of America Abstracts with Programs, 33, 381.

Manning, C. E. \& Bohlen, S. R., 1991. The reaction titanite + kyanite $=$ anorthite + rutile and titanite-rutile barometry in eclogites. Contributions to Mineralogy and Petrology, 109, $1-9$.

Miller, B. V. \& Stewart, K. G., 2002. Pluton ages in the Eastern Blue Ridge Province, North Carolina: constraints on timing of tectonics and metamorphism in deep levels of an Ordovician accretionary wedge complex. Geological Society of America Abstracts with Programs, 34, 41.

Miller, B. V., Stewart, K. G., Miller, C. F. \& Thomas, C. W., 2000. U-Pb ages from the Bakersville, North Carolina eclogite: Taconian eclogite metamorphism followed by Acadian and Alleghanian cooling. Geological Society of America Abstracts with Programs, Southeastern Section, 2, A-62.

Moecher, D. P., 2000. P-T conditions and timing of peak Taconian granulite facies metamorphism in the southern Blue Ridge. Geological Society of America Abstracts with Programs, 32, 113.

Moecher, D. P., Essene, E. J. \& Anovitz, L. M., 1988. Calculation and application of clinopyroxene-garnet-plagioclase-quartz geobarometers. Contributions to Mineralogy and Petrology, 100, 92-106.

Moecher, D. P. \& Miller, C. F., 2000. Precise age for peak granulite facies metamorphism and melting in the eastern Blue Ridge from SHRIMP U-Pb analysis of zircon. Geological Society of America Abstracts with Programs, 32, 63.

Möller, C., 1998. Decompressed eclogites in the Sveconorwegian (-Grenvillian) Orogen of SW Sweden; petrology and tectonic implications. Journal of Metamorphic Geology, 16, 641656.
Möller, C., 1999. Sapphirine in SW Sweden; a record of Sveconorwegian (-Grenvillian) late-orogenic tectonic exhumation. Journal of Metamorphic Geology, 17, 127-141.

Newton, R. C., 1966. Some calc-silicate equilibrium relations. American Journal of Science, 264, 204-222.

O'Brien, P. J., 1997. Garnet zoning and reaction textures in overprinted eclogites, Bohemian Massif, European Variscides: a record of their thermal history during exhumation. Lithos, 41, 119-133.

O’Brien, P. J. \& Rötzler, J., 2003. High-pressure granulites: formation, recovery of peak conditions and implications for tectonics. Journal of Metamorphic Geology, 21, 3-20.

Oh, C. W. \& Liou, J. G., 1990. Metamorphic evolution of two different eclogites in the Franciscan Complex, California, USA. In: Third International Eclogite Conference (ed. Okrusch, M.), pp. 41-53. Elsevier, Amsterdam.

Page, F. Z., 2001. Prograde and retrograde history of eclogites from the Bakersville area, N.C. Unpub. MSc Thesis, The University of Michigan, Ann Arbor, MI, USA.

Peacock, S. M., 1987. Creation and preservation of subductionrelated inverted metamorphic gradients. Journal of Geophysical Research, B, Solid Earth and Planets, 92, 12,763-12,781.

Perkins, D., Westrum, E. F. \& Essene, E. J., 1980. The thermodynamic properties and phase relations of some minerals in the system $\mathrm{CaO}-\mathrm{Al}_{2} \mathrm{O}_{3}-\mathrm{SiO}_{2}-\mathrm{H}_{2} \mathrm{O}$. Geochimica et Cosmochimica Acta, 44, 61-84.

Pognante, U., Compagnoni, R. \& Gosso, G., 1980. Micromesostructural relationships in the continental eclogitic rocks of the Sesia-Lanzo Zone (Italian Western Alps) a record of a subduction cycle. Rendiconti Della Societa Italiana Di Mineralogia E Petrologia, 36, 169-186.

Pouchou, J. L. \& Pichoir, F., 1984. A new model for quantitative X-ray microanalysis. Recherches Aéospatial, 3, 13-37.

Shervais, J. W., Dennis, A. J., McGee, J. J. \& Secor, D., 2003. Deep in the heart of Dixie: Pre-Alleghanian eclogite and HP granulite metamorphism in the Carolina Terrane, South Carolina, USA. Journal of Metamorphic Geology, 21, 65-80.

Stewart, K. G., Adams, M. G. \& Trupe, C. H., 1997. Paleozoic structural evolution of the Blue Ridge Thrust Complex. In: Paleozoic Structure, Metamorphism, and Tectonics of the Blue Ridge of Western North Carolina; Carolina Geological Society Field Trip and Annual Meeting (eds Stewart, K. G., Adams, M. G. \& Trupe, C. H.), pp. 21-32. Carolina Geological Society, Banner Elk, NC.

Stewart, K. G. \& Miller, B. V., 2001. The tectonic implications of 460 Ma eclogite along the Taconian Suture in the eastern Blue Ridge of North Carolina. Geological Society of America Abstracts with Programs, 33, 65.

Venturini, G., 1995. Geology, geochemistry and geochronology of the inner central Sesia Zone (Western Alps, Italy). Unpub. Thesis, Université de Lausanne, Institut de Geologie et Paleontologie, Lausanne, Switzerland.

Wang, L., Essene, E. J. \& Zhang, Y., 1999. Mineral inclusions in pyrope crystals from Garnet Ridge, Arizona, USA: implications for processes in the upper mantle. Contributions to Mineralogy and Petrology, 135, 164-178.

Willard, R. A. \& Adams, M. G., 1994. Newly discovered eclogite in the southern Appalachian Orogen, northwestern North Carolina. Earth and Planetary Science Letters, 123, 61-70.

Zhang, Y., 1998. Mechanical and phase equilibria in inclusionhost systems. Earth and Planetary Science Letters, 157, 209-222.

Received 4 June 2002; revision accepted 30 May 2003. 